\title{
Bölgesel Güvenlik Kompleksi Teorisi Kapsamında Somali ve Afrika Boynuzu'nun Güvenliği; Aktörler, Tehditler ve Riskler
}

\author{
Security of Somalia and Horn of Africa \\ within the Framework of Regional Security Complex; \\ Actors, Threats, and Risks
}

Güngör ŞAHİ**

\begin{abstract}
$\ddot{O} z$
Afrika Boynuzu ve Somali; Soğuk Savaş sonrasından günümüze iç savaş, terörizm, deniz haydutluğu, klan/kabile sorunu, kurakllk ve kitlık gibi konular ile dünya gündemini meşgul etmektedir. Çalışmanın amact, Bölgesel Güvenlik Kompleksi Teorisi kapsamında uluslararası deniz ticaretinin ana güzergâhlarından Aden Körfezi'ni kontrol eden Somali ve Afrika Boynuzu'ndaki güvenlik sorunlarının sebeplerini, bölge ülkelerinin ve uluslararası aktörlerin sorunlar karşısındaki rollerini incelemektir. Belirli bir coğrafi bölgedeki devletlerin aralarındaki tarihsel dostluk ve düssmanliktan kaynaklı bölgesel güç dengesini korumaya yönelik faaliyetler sonucu ortaya çıkan bölgesel krizlerin, küresel krizlere evrilme potansiyeli bulunmaktadır. Çalışma, bölgesel sorunlar karşısında, bölgesel ve uluslararası aktörlerin farkl insiyatifler alarak geliştirdikleri kapsamlı güvenlik yaklaşımının anlaşılması açısından önem arz etmektedir. Nitel araştırma yöntemlerinden içerik analizi kullanilarak bölge sorunlarının kaynağının kavramsal ve kuramsal çerçevesinin
\end{abstract}

\footnotetext{
* Dr. Öğr. Üyesi, Millî Savunma Üniversitesi, Atatürk Stratejik Araştırmalar Enstitüsü (ATASAREN), Strateji ve Güvenlik Araştırmaları Anabilim Dalı Öğretim Üyesi, ORCID: 0000-0001-6296-8568 e-posta: gsahin@msu.edu.tr.
}

Geliş Tarihi / Submitted: 10.06.2020

Kabul Tarihi / Accepted: 09.12.2020

873

Güvenlik

Stratejileri

Cilt: 16

Say1: 36 
oluşturulması, son dönemlerde bölgeye daha yakından ilgi göstermeye

Güvenlik Stratejileri

Cilt: 16

Sayı: 36 başlayan Türkiye gibi ülkeler ve uluslararası kuruluşların bölgenin güvenlik sorunlarını doğru tanımlaması, gelecekteki olası tehdit ve risklerin bertaraf edilmesi için gerekli görülmektedir.

Anahtar Kelimeler: Afrika, Afrika Boynuzu, Somali, Güvenlik, Tehdit.

\section{Abstract}

Horn of Africa and Somalia has been occupying the world agenda with issues such as civil war, terrorism, piracy, clan/tribe problems, drought, and famine since the end of the Cold War. This study aims to explore the reasons of the security problems in Somalia and Horn of Africa both of which control the Gulf of Aden, one of the main routes of the international maritime trade, and the roles of the regional states and international actors in the face of these problems within the framework of Regional Security Complex Theory. The regional crises, occurring as a result of military the activities to protect the regional balance of power emerging from the historical friendships of hostilities between the states in a specific geographical region, have the potential to evolve into global crises. This study is important helping to understand the comprehensive security approaches developed by the regional and international actors against the regional problems by taking different initiatives. In order to overcome possible future threats and risks, it is considered necessary to put forth the conceptual and theoretical framework of the regional problems by using content analysis, a qualitative research method, and to correctly identify the regional security problems by the international organization and by the states like Turkey which has started to show a closer interest to the region recently.

Keywords: Africa, Horn of Africa (HoA), Somalia, Security, Threat.

\section{Giriş}

Güvenlik, güç ve çatışma ilişkisi etrafında şekillenen uluslararası ilişkiler alanının önemli bir konusudur. Wolfers güvenliği, kazanılmış değerlere yönelik tehditlerin ya da bu tehditlerin varlığına dair korkuların bulunmaması olarak tanımlamaktadır. Bu bağlamda güvenlik, ulusların az veya çok sahip oldukları bir değer olarak 
yorumlanabilir. ${ }^{1}$ Uluslararası güvenlik kavramı; kullanılan uluslararası ilişkiler yaklaşımları, analiz birimi ve analiz düzeyine göre çatışmacı veya iş birlikçi olarak tanımlanabilir. Güvenlik, devletin bekası düşünüldüğünde ulusal güvenlik kavramına dönüşmekte ve realist bir bakış açısıyla çatışmacı; idealist bakış açısıyla ise barışın korunması için iş birlikçi davranmayı gerektirmektedir. $\mathrm{Bu}$ tartışma ortamında güvenlik kavramının ikinci planda kaldığını savunan Barry Buzan'a göre her iki yaklaşım da ulusal güvenliği, gücün ya da barışın türevi olarak ele almaktadır. Bu kapsamda güç eksenli yaklaşım, baskın konuma gelebilmesi için yeterli güce sahip bir devletin doğal olarak güvenlik elde edeceğini savunurken; barış eksenli yaklaşım, uzun süreli bir barış ortamının tüm devletlerin güvenliğini sağlayacağı sonucuna varmaktadır. $^{2} \mathrm{Bu}$ açıdan bakıldığında realist güvenlik çalışmaları devlet davranışına odaklanırken, idealist yaklaşım tüm sistem için uygulanabilir bir formül bulma arayışındadır.

Güvenlik çalışmalarında, bu iki paradigmanın dışında alternatif yaklaşımlar da gündeme gelmektedir. Bu noktada Buzan, güvenlik konseptiyle ilgili tanımlamaların anarşik yapıdaki uluslararası sistemin genelini yansıtmadığı fikrinden yola çıkarak, orta ölçekli bir alt-sistem analizi ortaya koymaktadır. ${ }^{3}$ Sadece birkaç devletin küresel ölçekte güce sahip olması gerçeğinden hareket eden bu anlayışa göre devletlerin büyük bir çoğunluğu için güvenlik kavramı, komşu devletler üzerinden anlamlandırılmaktadır. ${ }^{4}$ Barry Buzan tarafından kavramlaştııılan ve 1983 'te gündeme getirilen güvenlik kompleksi kavramına göre öncelikli ulusal güvenlik sorunları; aynı bölgeyi paylaşan iki ve daha

\footnotetext{
${ }^{1}$ Arnold Wolfers, Discord and Collaboration: Essays on International Politics, The John Hopkins Press, Baltimore, 1962, p. 150.

${ }^{2}$ Barry Buzan, People, States and Fear: The National Security Problem in International Relations, Wheatsheaf Books Ltd., Brighton, Sussex, 1983, p. 2.

${ }^{3}$ Ibid., p. 106.

${ }^{4}$ Barry Buzan and Ole Waever, Regions and Powers: The Structure of International Security, Cambridge University Press, New York, 2003, p. 14.
}

\section{5}

Güvenlik Stratejileri

Cilt: 16

Say1: 36 
fazla devleti kapsamakta, aynı bölgedeki devletlerin olası niyetlerinden kaynaklanmaktadır.

Güvenlik Stratejileri

Cilt: 16

Sayı: 36

Güvenlik sorununun niteliğine göre etkilenen ülke sayısı ve kompleksin boyutu değişebilmektedir. $\mathrm{Bu}$ açıdan bakıldığında güvenlik komplekslerinin kendi aralarına bir uluslararası alt-sistem görüntüsü verdiği de düșünülebilir. Bir bölgesel kompleksini, aynı medeniyet alanı içinde kültürel yakınlıkla şekillenen dostluk veya tarihsel düşmanlık ilişkileri olarak ortaya çıkan uzun süreli karşılıklı bağımlılıklar şekillendirmektedir. ${ }^{5} \mathrm{Bu}$ karşılıklı bağımlılıkta en önemli etken coğrafi yakınlıktır. Bir bölge içinde yer alan ülkelerin siyasi sınırlarını aşacak nitelikteki güvenlik sorunları, kompleksi oluşturan ülkelere coğrafi açıdan bir bütün görüntüsü vermektedir. Bu bütünlük askerî, siyasi, ekonomik, toplumsal ve çevresel güvenlik alanlarında belirgin hale gelmektedir. Devletler kendi bölgelerinde, kendi güvenliklerini ilgilendiren konuları karş1lıklı ilişkiler kapsamında güçleri oranında şekillendirmektedir. Uluslararası sistem bu bağlamda birbiriyle örtüşen ve bazıları birbirini kapsayan birçok bölgesel güvenlik kompleksinden oluşmaktadır. ${ }^{6}$

Soğuk Savaş sonrası dönemde ortaya çıkan yeni bölgesel sorunlar farklı bir sürece girildiğine işaret etmektedir. Bunun bir yansıması olarak daha önce örneğine pek rastlanmayan yeni güvenlik sorunları görülmeye ve bu sorunların çözümüne yönelik farklı bir yol izlenmeye başlanmıştır. $\mathrm{Bu}$ farklı yolların en belirgin olanlarından birini Kopenhag Okulu oluşturmuştur. Okul bu bağlamda yeni küresel sistemde medeniyetler arası değil, bölgeler arası veya bölge içi çatışmalardan doğan güvenlik sorunlarının varlığına işaret etmektedir. Soğuk Savaş öncesinde Okul, daha çok güvenlikleştirme ve sektörel güvenlik kavramları üzerinde durmuştur. Kapur ve Magon'un aktardığına göre Wilkinson, dünyayı bir bütün olarak algılayan Kopenhag Okulu kuramcılarının Avrupa değerlerini öncelediğini, güvenliğin yalnızca

\footnotetext{
${ }^{5}$ Ibid., p. 45.

${ }^{6}$ Buzan, ibid, p. 106.
} 
Bölgesel Güvenlik Kompleksi Teorisi Kapsamında

Somali ve Afrika Boynuzu'nun Güvenliği; Aktörler, Tehditler ve Riskler

Avrupa değerleri çerçevesinde sağlanabileceğini savunduklarını ifade etmektedir. ${ }^{7} \mathrm{Bu}$ nedenle Okul, Avrupa merkezci olması ve dünyanın diğer bölgelerindeki sorunları açıklayamaması nedeniyle eleştirilmiştir. Başar Baysal'ın vurguladığı üzere, yapılan bu eleştiriler çerçevesinde fikirlerini güncelleyen Weaver ve Buzan, Okul'un bu eksikliğini 2003 yılında yazdıkları Bölgeler ve Güçler isimli kitaplarıyla gidermişlerdir. ${ }^{8}$

Kopenhag Okulu'nun önde gelen teorisyenlerinden biri olan Barry Buzan'n, Soğuk Savaş sonrasında ortaya çıkan yeni uluslararası sistemi anlaşılır k1lmak için ortaya koyduğu "Bölgesel Güvenlik Kompleksi Teorisi (BGKT)", en genel ifadesiyle bölgesel nitelikli aktörlerin ortak güvenlik algılamalarının küresel nitelikli aktörlerden daha fazla etkiye sahip olduğunu ileri sürmektedir. ${ }^{9} \mathrm{Bu}$ çerçevede değerlendirildiğinde, belirli bir coğrafi bölgedeki devletlerin arasındaki tarihsel dostluk ve düşmanlıktan kaynaklı bölgesel güç dengesini korumaya yönelik faaliyetler sonucu ortaya çıkan bölgesel krizlerin küresel krizlere evrilmesi, bölgesel güvenlik kompleksi teorisi ile açıklanabilir. $\mathrm{Bu}$ çalışmada, Afrika Kıtası'nın en sorunlu devletlerini bünyesinde barındıran Afrika Boynuzu'na odaklanılmış; bu bölgenin uzun yıllardır en istikrarsız devleti olan Somali özelinde sorunlar, uluslararası aktörlerin çözüm yöntemleri ve başarı durumları tespit edilmeye çalışılmıştır.

Afrika kıtası; genç insan gücü, zengin yeraltı ve yerüstü doğal kaynakları ile 21 'inci yüzyılda gelişen, değișen ve kendini yenileyen bir aktör olarak gittikçe öne çıkmaya, küresel düzende daha etkin roller almaya kuvvetli bir adaydır. Bu büyük kıtanın doğusundaki Aden Körfezi'nin Afrika sahillerini oluşturan "Afrika Boynuzu (Horn of Africa - HoA) " ile kıtanın batısındaki Gine Körfezi, jeostratejik olarak

\footnotetext{
${ }^{7}$ Claire Wilkonson, "The Copanhagen School on Tour in Kyrgyzstan: Is Securitization Theory Useable Outside Europe", Security Dialogue, 2007, No 1, 5-25. Aktaran Saloni Kapur and Simon Mabun, "The Copenhagen School Goes Global: Securitization in the Non-West", Global Discourse, 2019, No 1, 1-4, p. 1.

${ }^{8}$ Başar Baysal, "20 Years of Securitization: Strengths, Limitations and A New Dual Framework", Uluslararası İlişkiler, 2020, No 67, 3-20, p. 9.

${ }^{9}$ Buzan and Waever, ibid, p. 45-48.
}

\section{7}

Güvenlik Stratejileri

Cilt: 16

Say1: 36 
878

Güvenlik Stratejileri

Cilt: 16

Sayı: 36

k1tanın güvenliğinin anahtarı konumundadır. Bu iki bölgedeki güvenlik sorunları Afrika'nın tamamını, hatta belli ölçüde küresel sistemi de etkileme potansiyeline sahiptir.

$\mathrm{Bu}$ çalışma; bölgesel güvenlik kompleksi teorisi bağlamında, bölgesel sorunlara bölgesel çözümler üretilebilirse, bölgesel güvenlik riskleri/tehditleri karşısında kapsamlı ve çok boyutlu çözümler geliştirilebilirse kalıcı barış ve istikrar sağlanabilir tezini savunmaktadır. Afrika Boynuzu bölgesi, özellikle Somali kaynaklı olarak 1992 yılından bu yana iç savaş, çatışma, istikrarsılılı ve yoksulluk girdabı içindedir. Somali, bölgesel güvenlik kompleksi teorisi ile kavramsallaştırıldığı şekliyle yaklaşık 30 yıldır başta bölge ülkeleri ile arasındaki tarihsel düşmanlık ve iç çatışmadan kaynaklı küresel bir sorun haline gelmiştir.

Makalenin amacı; deniz ulaşımının ana arterlerinden biri olan Aden Körfezi'ni kontrol eden Afrika Boynuzu'nun küresel ölçekte güvenlik analizini yapmak, güvenlik sorunlarının Afrika Boynuzu ülkeleri başta olmak üzere Afrika kıtasına olan etkilerini incelemek, önleyici tedbirler geliştirilmesine katkı sağlamaktır. Makalenin önemi; bölgeye yönelik güvenlik sorunlarını anlamaya ve açıklamaya çalışan güvenlik literatürüne bütünsel bir bakış açısı sunma gayretinden kaynaklanmaktadır. Makalede veri toplama yöntemi olarak literatür taraması ve içerik analizi kullanılmıştır.

Afrika Boynuzu'nun çözüme kavuşturulamayan sorunları, Somali başta olmak üzere bölgesel ve kıtasal etkilere yol açmaktadır. $\mathrm{Bu}$ kapsamda bölgeye ilgi gösteren tüm ülkeler ve uluslararası kuruluşların bu bölgede icra edecekleri faaliyetlerde çeşitli güvenlik sorunlarıyla karşılaşacakları ve bu durumdan kaçınamayacakları, ayrıca Somali merkezli El-Şebab Terör Örgütü’nün bölge için tehdit oluştururken bu tehdidin bölge dışına taşmayacağı, kıtasal veya küresel boyuta erişmeyeceği varsayılmaktadır.

\section{Somali ve Afrika Boynuzu Güvenlik Sorunları}

Afrika Boynuzu bölgesi, Afrika'nın en doğusundaki “çıkıntı şeklindeki" bölgeye verilen isimdir. Bölgenin sınırlarını belirlemede öne çıkan birinci ve en genel yaklaşımda; bu bölgenin kapsadığı ülkeler "dar" tanımlanarak Cibuti, Eritre, Etiyopya, Somali olarak kabul 
Bölgesel Güvenlik Kompleksi Teorisi Kapsamında

Somali ve Afrika Boynuzu'nun Güvenliği; Aktörler, Tehditler ve Riskler

edilmektedir. İkinci yaklaşımda; Afrika Boynuzu "geniş" tanımlanarak belirtilen dört ülkenin yanı sıra Kenya, Sudan, Güney Sudan, Uganda olmak üzere dört ülke daha bu bölge içinde kabul edilmektedir." Üçüncü yaklaşımda ise bölge tanımına dokuzuncu ülke olarak daha güneydeki Tanzanya da eklenmektedir. ${ }^{11}$ Bu makalenin hazırlanmasında esas alınan tanım, ikinci yaklaşımda olduğu gibi bölgeyi "geniş" tanımlayan yani sekiz ülkeyi kapsayan yaklaşım olmuştur. Afrika Boynuzu'nun doğu sınırlarını her biri ayrı stratejik önemde olan Kızıl Deniz, Bab-ül Mendep Boğazı, Aden Körfezi ve Batı Hint Okyanusu (West Indian Ocean-WIO) oluşturmaktadır. Bahse konu bu su hatının doğusunda ise Afrika'yı Orta Doğu'ya bağlayan Yemen yer almaktadır.

Afrika Boynuzu, jeostratejik ve jeoekonomik konumu, bölge ülkeleri arasındaki tarihsel dostluk/düşmanlık ve terörizm kaynaklı istikrarsızlık, iç savaş, kuraklık, yoksulluk, küresel deniz ticareti ve enerji arzını engelleme potansiyeli sebebiyle küresel aktörlerin ilgi alanındadır. Bu sorunların merkezindeki Somali, bölgesel güvenlik kompleksi kapsamında Afrika Boynuzu güvenliğinin sağlanabilmesi için anahtar ülke haline gelmiştir.

1992 yılında Somali'de patlak veren çok taraflı iç savaş ve bu süreçteki yıkıcı kuraklık 300 binden fazla insanın ölümüne yol açmıştır. Ortaya çıan kritik güvenlik sorunları karşısında BM tarafından Somali'de başlatılan UNOSOM I, ${ }^{12}$ UNITAF $^{13}$ ve UNOSOM II

\footnotetext{
${ }^{10}$ Encyclopedia Britannica, "Horn of Africa", http://global.britannica.com/place/Hornof-Africa (Erişim Tarihi: 06.06.2020).

${ }^{11}$ New World Encyclopedia, "Horn of Africa", http://newworldencyclopedia.org/ entry/Horn of Africa (Erișim Tarihi: 06.06.2020).

12 Bkz. UN̄̄̄̄OM I (United Nations Operation in Somalia I), April 1992 - March 1993, https://peacekeeping.un.org/sites/default/files/past/unosomi.htm (Erişim Tarihi: 06.06.2020).

${ }^{13}$ UNITAF (Unified Task Force) ABD Liderliğinde Birleşik Görev Kuvveti 1992 y1lı sonlarında 33 bin civarındaki askerden (28 bin ABD'li) oluşturulmuştur. UNITAF gücü, Ekim 1993'te icra ettiği operasyonda 18 ABD askerinin öldürülüp 78'i yaralanması, iki adet Blackhawk helikopterinin de düşürülmesiyle ABD kamuoyunda büyük bir huzursuzluk oluşmuştur. Bunun sonucu olarak da ABD askerlerinin büyük kısmını Somali'den çekmek
}

\section{9}

Güvenlik Stratejileri

Cilt: 16

Say1: 36 

perspektifte icra edilmiştir. Bu yönüyle Somali iç savaşı ve ortaya çıkan tehdit durumu BM'nin kuruluşundan beri icra ettiği en tehlikeli ve zor görevlerden biri olmuştur. BM sözleşmesine göre müdahalenin gerçekleşebilmesi için ev sahibi ülkenin talebi/uygun bulması gerekirken, o dönem Somali'de devlet sistemi çökmüş olduğundan BM'nin müdahale kararı BM sözleşmesinin VII'nci Bölümü kapsamında alınmış ve ilk defa olarak BM güçlerine ihtiyaç durumunda silah kullanma yetkisi de verilmiştir. ${ }^{15}$ BM'nin UNOSOM II harekâtı çok boyutlu bir barışı koruma harekâtı olarak sadece askerî araçlarla değil polislerin eğitimi, bölgesel idarî yapıların ve hukuk sisteminin yeniden yaşama geçirilmesi dâhil geniş bir kapsamda icra edilmiştir. Bu faaliyetler arasında önemli bir yer tutan konu da insani yardımın ihtiyaç sahiplerine ulaştırılması olmuştur. $^{16}$

Somali'de devleti yeniden inşa etmek için 2000 Arta Barış Anlaşması ile başlayan süreç sonunda Ekim 2004'te Federal Geçiş Hükümeti (Transnational Federal Government-TFG) kurulmuştur. Fakat Federal Geçiş Hükümeti, ülke içi gruplardan ve komşu ülkelerden şiddetli bir muhalefetle karşılaşmış, 2008'deki Cibuti Anlaşması ile ülkedeki güç paylaşımı üzerinde genel bir uzlaşı sağlanmıştır. 23 Şubat 2012'de düzenlenen Londra Konferansı'na El Şebab örgütü hariç Somali içindeki ve dışındaki tüm aktörler davet edilmiş, Ağustos 2012 tarihinde Federal Geçiş Hükümeti'nin görev süresi dolacağı için yeni anayasanın onaylanması, yeni meclis ve

durumunda kalmıştır. Bu tepkisel yaklaşım, ABD'nin 1994'teki Ruanda iç savaşına yeterince aktif dâhil olmasını da engelleyen bir faktör olmuştur. Geoffrey Parker, Cambridge Savas Tarihi, Türkiye İs Bankası Kültür Yayınları, 2'nci Basım, İstanbul, 2014, s. 433.

${ }^{14}$ Bkz. UNOSOM II (United Nations Operation in Somalia II), Mart 1993 - Mart 1995, https://peacekeeping.un.org/sites/default/files/past/unosom2.htm (Erişim Tarihi: 06.06.2020).

${ }^{15}$ United Nations, The United Nations and Somalia (1992-1996), The United Nations Blue Books Series, Volume VIII, Department of Public Information, New York, 1996, p. 3-4, https://digitallibrary.un.org/record/205118 (Erişim Tarihi: 06.06.2020).

${ }^{16}$ Ibid., p. 4. 
Bölgesel Güvenlik Kompleksi Teorisi Kapsamında

Somali ve Afrika Boynuzu'nun Güvenliği; Aktörler, Tehditler ve Riskler

cumhurbaşkanının seçilmesi, yeni bir kabine oluşturulması gerektiği kararlaştırılmıştır. ${ }^{17}$

Bu kapsamda; 01 Ağustos 2012 tarihinde Somali Federal Hükümeti Geçici Anayasası kabul edilmiş, 20 Ağustos 2012 tarihinde meclis görevine başlamış, Eylül 2012'de ilk cumhurbaşkanı seçilmiştir. Somali Cumhurbaşkanlığ1 görevini halen 08 Şubat 2017 tarihinde seçilen Muhammed Abdullah Muhammed (Farmajo) yürütmektedir. ${ }^{18}$ Uluslararası toplumun Somali'ye yönelik taahhütleri ve Somali yönetiminden beklentilerini içeren "Yeni Ortaklık Antlaşması" 11 Mayıs 2017 tarihinde Londra'da düzenlenen yüksek düzeyli Somali Konferansı'nda kabul edilmiştir. Konferansta kabul edilen Güvenlik Paktı, Somali'de ulusal güvenliğin sağlanması açısından uluslararası katılımcıların güvenlik reformlarına sağlayacağı finansal ve danışmanlık desteklerini kapsamaktadır. ${ }^{19}$ Başta Birleşmiş Milletler olmak üzere uluslararası örgütlerin ve uluslararası toplumun desteğini alan Somali, Weber'in meşru şiddet tekeli olarak tanımladığı devlet kurumlarını ve otoritesini tam olarak oluşturamamıştır. Ülkenin her noktasında devlet kontrolü sağlanamamış, şiddet olayları meşru güvenlik güçleri tarafindan önlenememiş ve kırılgan devlet endeksinde ${ }^{20}$ Yemen'den sonra ikinci sırada yer almaya devam etmiştir. ${ }^{21} \mathrm{Bu}$ kapsamda, Somali'de istikrarsızlığa sebep olan konuların incelenmesi önem arz etmektedir.

17 Oktay Bingöl, “Somali'de Barış ve Kalkınma Sürecinde Türkiye'nin Rolü”, Gazi Akademik Bakıls, 2013, Sayı 13, 81-106, s. 92.

18 Güngör Şahin (Ed.), Somali Barış, Istikrar ve Kurumsallaşma, Milli Savunma Üniversitesi Yayınları, İstanbul, 2019, s. 27.

${ }^{19}$ A.g.e., s. 70.

${ }^{20}$ Fund for Peace, "Fragile States Index 2020", https://fragilestatesindex.org/ (Erişim Tarihi: 06.06.2020).

${ }^{21}$ Sedat Aybar, “Afrika Boynuzu'nun Kapasite İnşasında Türkiye'nin Rolü”, TASAM, https:/tasam.org/tr-TR/Icerik/39026/afrika_boynuzunun_kapasite_insasinda_turkiyenin_rolu (Erişim Tarihi: 06.06.2020) 
882

Güvenlik Stratejileri

Cilt: 16

Sayı: 36

\subsection{Terör Sorunu: El-Şebab ${ }^{22}$}

El-Şebab adıyla tanınan Somali orijinli bu örgütün Arapça tam adı "Harakât Al-Shabaab Mujahideen" ya da İngilizce kullanıldığı şekliyle "Movement of the Warrior Youth", ${ }^{23}$ yani "Mücahit Gençlik Hareketi"dir. Dünya literatüründe genel olarak kısaltılmış şekliyle "El-Şebab" veya "Eş-Şebab" olarak ifade edilmektedir. Makalede de "El-Şebab" veya "El-Şebab Terör Örgütü" olarak kullanılmaktadır.

El-Şebab'in kuruluşundan günümüze tarihi geçmişi ve yaptı̆̆ 1 eylemler dikkate alındığında, Somali başta olmak üzere Afrika Boynuzu'ndaki ülkeler için temel güvenlik tehditlerinden birisi olduğu görülmektedir. El-Şebab bir yönüyle Somali'de 1990'l1 yıllarda baş gösteren iç savaş sonucunda ortaya çıkan ve 2006 yılında dağıtılan İslam Mahkemeleri Birliği (Islamic Courts Union-ICU) mensuplarının radikal kısmının oluşturduğu bir yapılanmadır. El-Şebab, İslam Mahkemeleri Birliğgi'nin yaptığı gibi ülkede "şeriat yasalarını" esas alıp uygulamaya zorlamakta, örgüt üyeliği için Somali'de etkin olan kabile/klan yapısından faydalanmaktadır. Stig Jarle Hansen, El-Şebab üyeleri ile görüşme dâhil derinlemesine yaptığ çalışmada, El-Şebab'1 uluslararası cihat retoriği ile Somali milliyetçiliğini güçlü bir şekilde birleştiren hibrit bir İslamcı örgüt olarak tanımlamaktadır. Bu özelliği ile yabancı savaşçıları kendi saflarına çekebilmektedir. El-Şebab'ı iki yönlü hibrit bir yapıya iten nedenlerden biri de Etiyopya, $\mathrm{ABD}^{24}$ ve

22 El-Şebab Terör Örgütü bazı dokümanlarda El-Şebap veya Al-Şabab, İngilizce dokümanlarda da Al-Shabaab veya Al-Shabab olarak kullanılmaktadır.

${ }^{23}$ Home Office, "Country Policy and Information Note Somalia: Al Shabaab", Version 3.0, November 2020, p. 16, https://assets.publishing.service.gov.uk/government/ uploads/system/uploads/attachment_data/file/933800/Somalia-_Al_Shabaab_-_CPIN_ - V3.0e.pdf (Erişim Tarihi: 20.11.2020).

${ }^{24}$ ABD, El-Şebab'1 Mart 2008'den beri yabancı terörist örgüt olarak kabul etmektedir. ABD Dış İlişkiler Konseyine göre örgüt Somali'yi köktenci (fundamentalist) bir İslam devleti haline getirmeye çalışmaktadır. Holly Yan, "What is Al-Shabaab, and What does It Want?", CNN, 22 February 2015, http://edition.cnn.com/2014/12/02/world/ africa/al-shabaab-explainer/ (Erişim Tarihi: 07.06.2020). 
Bölgesel Güvenlik Kompleksi Teorisi Kapsamında

Somali ve Afrika Boynuzu'nun Güvenliği; Aktörler, Tehditler ve Riskler

Afrika Birliği'nin (AfB) El-Şebab'ı askerî açıdan yenmek için gösterdikleri çabalar olmuştur. ${ }^{25}$

El-Şebab 2007 yılından itibaren eylemleriyle dünyada tepki çekmeye başlamıştır. Somali'de uluslararası yardım personeline, basın mensuplarına, sivil liderlere ve Afrika Birliği barış gücü personeline yönelik saldırılar; Somali dışında 2010 Temmuz ayında Uganda'nın başkenti Kampala'da Dünya Kupası final maçını izlemek için bir araya gelmiş insanları hedef alan ve 70 kişinin öldüğü intihar bombacısı eylemi kuruluş döneminin dikkat çeken eylemleri olmuştur. El-Şebab'ın 4-5 bin kişilik bir gücü kontrol ettiği düşünülmektedir. 2012 yılı Şubat ayında o dönemdeki lideri Ahmed Abdi Godane ile El-Kaide lideri Ayman al-Zawahiri birlikte bir video yayınlayarak iki örgütün ittifak halinde olduklarını dünyaya ilan etmişlerdir. El-Şebab'ın finans desteğini, bölge insanlarından ve ticaretinden "vergi" adı altında toplanan paralar oluşturmaktadır. BM raporlarında 70-100 milyon Dolarlık gelir elde edildiği ifade edilmektedir. ${ }^{26}$ Günümüzde ağırlıkla Somali merkez ve güneyinde faaliyetleri sınırlandırılmış olan El-Şebab, Şura Meclisi ile yönetilmektedir. ${ }^{27}$

El-Şebab'ın 21 Eylül 2013 tarihinde Kenya'nın başkenti Nairobi'de bulunan Westgate Mall'a (Alışveriş Merkezine) yaptığı saldırı küresel etki yaratmış, ülkelerin bu bölgeye ilişkin güvenlik algılarını aşındırmıştır. Dört gün süren çatışmalar sonucunda saldırıyı gerçekleştiren dört terörist ölü ele geçirilirken, binada bulunan 67 kişi ölmüş, 200 kişi de yaralanmıştır. Kenyalı araştırma komisyonunun raporunda bu saldırının, Kenya Silahlı Kuvvetleri'nin AMISOM'a (African Union Mission in Somalia-AfB'nin Somali Misyonu) katıldığ Ekim 2011'den bu yana 28'inci terörist saldırı olduğu belirtilmiştir. Kenya'nın El-Şebab saldırılarına bu denli çok maruz kalmasının

\footnotetext{
${ }^{25}$ Stig Jarle Hansen, Al-Shabaab in Somalia: The History and Ideology of a Militant Islamist Group, Oxford University Press, 1st Edition, 15 Ocak 2013, p. 145-147.

${ }^{26}$ Yan, ibid, (Erişim Tarihi: 07.06.2020).

${ }^{27}$ Critical Threats Sitesi, "Al Shabaab Leadership Profiles", http://www.criticalthreats.org/ somalia/al-shabaab-leadership (Erişim Tarihi: 07.06.2020).
}

\section{3}

Güvenlik Stratejileri

Cilt: 16

Say1: 36 
884

Güvenlik Stratejileri

Cilt: 16

Sayı: 36 nedenlerinden birinin, 600 bin'den fazla Somalili mültecinin Kenya'da ikamet ediyor olması olarak belirlenmiştir. ${ }^{28}$ BM Güvenlik Konseyi'nin (BMGK) 12 Kasim 2013 tarih ve 2124 say1lı kararı ile AMISOM ve Somali Silahlı Kuvvetleri (Somali National Forces-SNF) yeni bir harekât konsepti ile daha da güçlendirilmiştir. ${ }^{29}$

El-Şebab'ın son dönemlerde yeni taktikler belirleyerek Somali'de, özellikle de Mogadişu'da AMISOM birliklerine ve Somali halkına karşı etkili eylemler yaptığ 1 görülmektedir. BBC'de yayımlanan röportajda AfB Komisyonu Somali Özel Temsilcisi ${ }^{30}$ Büyükelçi Francisco Madeira, El-Şebab ile mücadelede AMISOM'un ve Somali Silahlı Kuvvetleri'nin yetersiz kaldığını, uluslararası desteğe gereksinim duyduklarını ifade etmiştir. Röportajı yapan muhabir bu durumun "Afrika'nın sorunlarına Afrikalı çözümler üretmek" prensibine uyup uymadığı yönündeki sorusuna verdiği yanıtta, "Afrika'daki tüm sorunlara Afrikalı çözümler esas olmakla birlikte, dışarıdan yani uluslararası toplumdan yardım istemeye engel bir durum olmadığını, önemli olan hususun bu kararın Afrika tarafından alınmış olması gerektiğini”" ifade etmiştir. ${ }^{31}$

El-Şebab'ın, çocuk yaştaki kişileri saflarına katarak terör eylemlerine yönlendirdiği gözlenmektedir. 2016 Mart ayında Somali’nin kuzeyinde yarı otonom bir yapıya sahip olan Puntland bölgesinde eylem gerçekleştiren El-Şebab üyelerine karşı yürütülen operasyonda çok sayıda örgüt üyesi çocuk da yakalanmıştır. Çocuklarla yapılan görüşmelerde bir kısmı kendilerine "lider" olacakları yönünde vaatte bulunulduğu, bir kısmına "eğitimlerinin destekleneceği” yönünde söz verildiği, bir kısmının da ailelerine yüklenen yasadışı vergi borcu

${ }^{28}$ Paul D. Williams, "After Westgate: Opportunities and Challenges in the War Against AlShabaab", International Affairs, The Royal Institute of International Affairs, 2014, p. 907. https://ciaotest.cc.columbia.edu/journals/riia/v90i4/f 0032208 26204.pdf (Erișim Tarihi: 07.06.2020).

${ }^{29}$ Ibid., p. 908.

${ }^{30}$ AfB Komisyonu Somali Özel Temsilcisine kısaca "SRCC" (Special Representative of the Chairperson of the African Union Commission) denmektedir.

31 AMISOM Website, "BBC's Tomi Oladipo Interviews SRCC Madeira", http://amisom-au.org/2016/03/8157, (Erişim Tarihi: 07.06.2020). 
yüzünden karşılık olarak çocuklarını veya eşlerini vermeye zorlandıkları tespit edilmiştir. Örgütün çocuklara ulaşımda kullandığ 1 kaynaklardan birisinin dini eğitim veren "medreseler" olduğu, bu okullarda birçok çocuğun radikalleşme riski altında olduğu belirlenmiştir. ${ }^{32}$

El-Şebab, cihat retoriği ile Somali milliyetçiliğini birleştiren hibrit bir ideoloji ile güç kazanmış, katı kuralları ile bilinen Vahabilik ideolojisini benimsemiştir. El-Şebab'ın başka bir özelliği de güçlü bir liderliğe sahip olmasıdır. Liderliğe bu gücü veren faktörlerin başında bu kişilere atfedilen (adeta ruhani boyutlara varan) manevi değerlilik gelmektedir. Örgütün çevresine saldığ 1 korku ve dehşet, bölgelerinin bask1 altında tutulmasında önemli rol oynamaktadır. Diğer taraftan işsiz, yoksul ve güçsüz insanlara maaş verebilecek bir sistem kurmuş olmaları, bu insanların isteyerek veya istemeyerek örgütün bir parçası olmalarına olanak sağlamaktadır. Örgüt, lider kadrolarla savaşçılar arasında sosyal ve yaşam tarzı olarak büyük fark oluşmasını önleyerek gücünü korumak istemektedir. Örgütün, cihat retoriğine rağmen Müslüman ve Somalililere yönelik eylemleri, organize suç örgütü görüntüsü, çocukları zorla örgüte alması, zorla para toplaması vb. hususlar El-Şebab'a yönelik operasyon ve faaliyetlerde kapsamlı bir yaklaşımla askerî olmayan araçların da yeterince aktif kullanımına ihtiyaç olduğunu göstermektedir. El-Şebab Terör Örgütü varlığını sürdürdüğü müddetçe, Somali ve Afrika Boynuzu bölgesinin istikrara kavuşması mümkün görünmemektedir.

\subsection{Deniz Haydutluğu}

Modern teknolojinin imkânlarını kullanan deniz haydutlarının hedefinde denizciler, balıkçılar ve deniz taşıma şirketleri vardır. 20002006 yılları arasında dünyada deniz haydutluğu eylem sayısı 2,463'dür (y1llk ortalama 352). 1994-1999 yılları arasında ortalama 209 iken 2000’li y1llarda belirgin bir artış görülmektedir. Deniz haydutluğu bu süre

32 AMISOM Website, "Al Shabaab Using Child Soldiers in Desperate Effort to Control Somalia", http://amisom-au.org/2016/03/al-shabaab-using-child-soldiers-indesperate-effort-to-control-somalia/ (Erişim Tarihi: 07.06.2020). 
886

Güvenlik Stratejileri

Cilt: 16

Sayı: 36

içinde ağırlıkla Güneydoğu Asya, Malakka Boğazları dâhil Endonezya takımadası civarında yoğunlaşırken, 2005 yılında hiç beklenmedik bir anda Somali'de tekrar ortaya çıkmıştır. Uluslararası toplumun hazırlıksız yakalandığı bu yeni durum; deniz ulaştırmasının \%7,5'inin, Avrupa'ya sevk edilen petrolün \%30'unun sevk edildiği Aden Körfezi (ya da Afrika Boynuzu) bölgesinin emniyetinin sorgulanmaya başlamasına neden olmuştur. Bu bölgede kayitlara geçen ilk önemli deniz haydutluğu girişimi 2005 Kasım ayında lüks yolcu gemisi Seaborn Spirit gemisine yönelik saldırı olmuştur. 2005 yılı içinde bu bölgede 35 saldırı gerçekleşmiştir. Gelişmelerin endișe verecek boyutlara doğru evrildiğini gören Birleşmiş Milletler Güvenlik Konseyi (BMGK), 15 Mart 2006 tarihinde yayımladığı bildiriyle Somali'ye dikkat çekmiştir. Özellikle Somali'ye gönderilen insani yardım malzemelerine yönelik saldırıların yoğunlaşmaya başlaması, uluslararası toplumun birlikte hareketi yönünde belirleyici olmuştur. ${ }^{33}$ Deniz haydutluğu suçlamasıyla yakalanan Somalili şüphelilerden birine Amerikalı askerî hâkimin "kendisi ve arkadaşlarının neden silah bulundurduğu" sorusuna "Ben Somaliliyim, silah bizim hükûmetimizdir!" diye verdiği yanıt ${ }^{34}$ bu bölgede baş gösteren olayların kültürel kodları hakkında ipuçları sunmaktadır.

Uluslararası toplumun kısmî müdahalesi ile 2006 yılında azalma gösteren deniz haydutluğu faaliyetleri 2008 yılında zirve yapmış, bu süreçte BMGK aldığ kararlarla uluslararası toplumun askerî tedbirler almasını gerekli kılmıştır. Başlangıçta deniz haydutluğunu azaltan etkenlerden birisi o dönemde Somali merkez ve güney bölgelerinde hâkimiyetini tesis eden İslam Mahkemeleri Birliği'nin (ICU) deniz haydutluğunu şeriata aykırı ilan etmesi olmuştur. Ancak ilerleyen aylarda ICU'nun aşırı unsurlarının Etiyopya ile çatışmaya girmesiyle

${ }^{33}$ Akif Emre Öktem ve Bleda R. Kurtdarcan, Deniz Haydutluğu ve Korsanlık: Tarihi ve Hukuki Boyutlarlyla, Denizler Kitabevi, Birinci Bask1, İstanbul, 2011, s. 49-50.

${ }^{34}$ Michael Bahar, "Attaining Optimal Deterrence at Sea: A Legal and Strategic Theory for Naval Anti-Piracy Operations", Vanderbilt Journal of Transnational Law, 2007, Number 1, p.19, https://papers.ssrn.com/sol3/papers.cfm?abstract_id=982679 (Erişim Tarihi: 07.06.2020). 
Somali 2006 Aralık ayında Etiyopya'nın işgaline uğramıştır. Bu işgal ICU'nun ülke üzerindeki kısmî hâkimiyetini de kaybetmesine neden olmuş, bu da deniz haydutluğunu engelleyici dinî otoritesinin zayıflaması sonucunu doğurmuştur. ${ }^{35}$

Deniz haydutluğu ile mücadele kapsamında NATO, AB, ABD, Çin gibi ulusararası örgüt ve devletler etkin şekilde faaliyet göstermiştir. 2008-2009 yıllarında Aden Körfezinde yoğunlaşan deniz haydutluğu olayları karşısında ticaret gemilerinde gittikçe artan tedbirler de dikkat çekmektedir. Bu tedbirlerden bazıları Uzun Menzilli Akustik Cihazlar (Long Range Acoustic Devices-LRAD), lazer 1şını, basınçlı su hortumları, kesici ağlar ve fens telleri, bot tuzakları, kötü kokulu sıvılar ve 2013 yılından itibaren yaygın olarak uygulanmaya başlanan "silahlı muhafizlar"dır. ${ }^{36}$

Afrika Boynuzu bölgesinde "tarihin sisleri arasından yeniden beliren" deniz haydutluğu sorunu etkileri bakımından küresel nitelik kazanmış ve bu bölgedeki otorite boşluğu ve güvenlik zafiyetinin ortaya çıkardığ 1 risk ve tehditler yaşanarak öğrenilmiştir. NATO'nun Okyanus Kalkanı Harekâtı (Operation Ocean Shield-OOS), AB'nin ATALANTA Harekâtı, ABD liderliğinde oluşturulan Birleşik Görev Kuvveti (Combined Task Force-CTF), ayrıca müstakil olarak bu bölgede askerî gemi bulunduran Çin, Japonya, Kore gibi ülkelerin tüm çabası bu bölgede kalıcı istikrarın sağlanması hedefine yönelmiştir. Aden Körfezindeki deniz haydutluğu sorunu son on yılda ulaştırma ve taşıma bağlamında küresel ekonomik istikrarı olumsuz etkilemiş, günümüzde ise alınan yoğun tedbirlerle nisbi istikrara kavuşulmuştur. Alınan tedbirlerin gevşetildiği dönemlerde "öğrenilmiş" böyle bir yasadışı örgütlenmenin bölgede gelecekte tekrar ortaya çıkabileceği öngörülmektedir.

\footnotetext{
35 Öktem ve Kurtdarcan, a.g.e., s. 51.

${ }^{36}$ Marine Insight, "18 Anti-Piracy Weapons for Ships to Fight Pirates", 25 October 2019, https://www.com/marine-piracy-marine/18-anti-piracy-weapons-for-ships-to-fight-pirates/ (Erişim Tarihi: 07.06.2020).
}

\section{7}

Güvenlik Stratejileri

Cilt: 16

Say1: 36 
888

Güvenlik Stratejileri

Cilt: 16

Sayı: 36

\subsection{Kabile/Klan Sorunu}

Afrika ülkelerinin 1960'lı yıllardaki bağımsızlık mücadelesi sürecinde ortaya çıkan "kitlesel göçler", son 30 yılda yaşanan iç savaş ve çatışmalar, BM denetiminde veya ülkelerin kendi kontrolünde oluşturulan "mülteci kampları" nedeniyle birçok Afrika ülkesinde komşu ülke insanlarının da yaşadı ğı çok etnik gruplu toplumsal yapılar oluşmuştur. Bu bağlamda Afrika Boynuzu'nda özellikle Somalililer Bu bağlamda, Somaliler, Afrika Boynuzu'nda özellikle komşu ülkelerde, büyük miktarlarda bulunmaktadır. Kenya'da yaşayan Somalililer, Etiyopya'da yaşayan ve Somalice konuşan kabileler, Cibuti'de yaşayan Somalili Issa kabilesi bunun belirgin örnekleridir. Afrika Boynuzu bölgesi etnik açıdan incelenirken "fiziksel görünüş ve özelliklerden ziyade konuştukları dil ve kültürel özelliklerine göre" ${ }^{37}$ bir sinıflandırma ortaya konmasının daha isabetli sonuçlar vereceğini savunan akademisyenler de vardır.

1960'lı yıllarda bağımsızlıklarını kazanmaya başlayan Afrikalı ülkelerin sonraki yıllarda karşı karşıya kaldıkları yıkıcı etnik sorunların temel nedenlerinden birisi "sömürge döneminde ülke içindeki etnik gruplar (kabileler/klanlar) arasına ekilmiş nefret tohumları" olmuştur. Afrika Boynuzu'na bakıldığında, Somali'yi ve çevresini saran iç çatışmaların bir nedeni olarak "kabile/klan" ayrışması ve anlaşmazlıkları olduğu görülmektedir. Somali, bu devleti oluşturan kabilelerin/klanların kendi toplumları üzerindeki etkisi ile iç savaşa, bitmeyen anlaşmazlıklara ve yönetim kavgalarına sürüklenmiștir. Yine Somali özelinde ele alındığında, iç savaşın sonucunda yerinden edilmiş yüzbinlerce insan, sosyal ve ekonomik krizi derinleştirmiştir. Somali'deki iç savaşın neden olduğu göçler sonucunda 1,1 milyon kişi yerinden edilmiştir. Başkent Mogadişu'da bu miktar 369 bin kişi civarındadır. ${ }^{38}$ İç savaş, kıtlık,

37 Orville Boyd Jenkins, "Race and Ethnicity in the Horn of Africa", 25 January 2006, http://strategyleader.org/peopledefinitions/raceandethnicity.html (Erişim Tarihi: 07.06.2020). 38 UN High Commissioner for Refugees, "Somalia March 2016: Total Internally Displaced Persons", 12 March 2016, http://reliefweb.int/map/somalia/somalia-march2016-total-internally-displaced-persons (Erişim Tarihi: 07.06.2020). 
güvende olma ihtiyacı veya kişisel nedenlerle yapılan bu ülke içi yer değiştirmeler toplumsal sorunu daha da büyütmektedir.

Afrika Boynuzu etnik grupları incelendiğinde, kendine özgü bir dile ve kültüre sahip birçok etnik grup bulunduğu görülmektedir. Mevcudu "on milyondan fazla" olan etnik gruplar aşağıdaki gibi siralanabilir:

- Etiyopya ve Kenya'da yaşayan Oromolar 30 milyon,

- Etiyopya, Sudan, Somali, Eritre ve Cibuti'de yaşayan Amharalar 20 milyon,

- Somali, Cibuti, Etiyopya ve Kenya'da bulunan Somalililer 15-17 milyon. ${ }^{39}$

Afrika Boynuzu bölgesini yakından ilgilendirmesi bakımından dikkati çeken üç etnik grubun "Amharalar", "Oromolar" ve "Somalililer" olduğu, bu üç etnik grubun bu bölgenin genel dokusunu şekillendirdiği söylenebilir. Somali halkının kabile yapılanması oldukça karmaşıktır. Dört büyük kabile ve bu kabilelere ait alt gruplar ile küçük kabileler vardır. ${ }^{40}$ 15-17 milyon ile Afrika Boynuzu'na yayılmış Somalili nüfusu Şekil:1; Somali'deki terörizm, toplumsal, ekonomik ve siyasi sorunlar çözülmediği sürece bölge için istikrarsılılk ve risk kaynağı olmaya devam edecektir.

\footnotetext{
${ }^{39}$ Saylor Academy, "Ethnic Groups in Africa", 2011, http://www.saylor.org/site/wpcontent/uploads/2011/04/ Ethnic-groups-in-Africa.pdf (Erişim Tarihi: 07.06.2020).

${ }^{40}$ Şahin (Ed.), a.g.e., s. 53.
}

\section{9}

Güvenlik Stratejileri

Cilt: 16

Say1: 36 


\section{0}

Güvenlik

Stratejileri

Cilt: 16

Sayı: 36

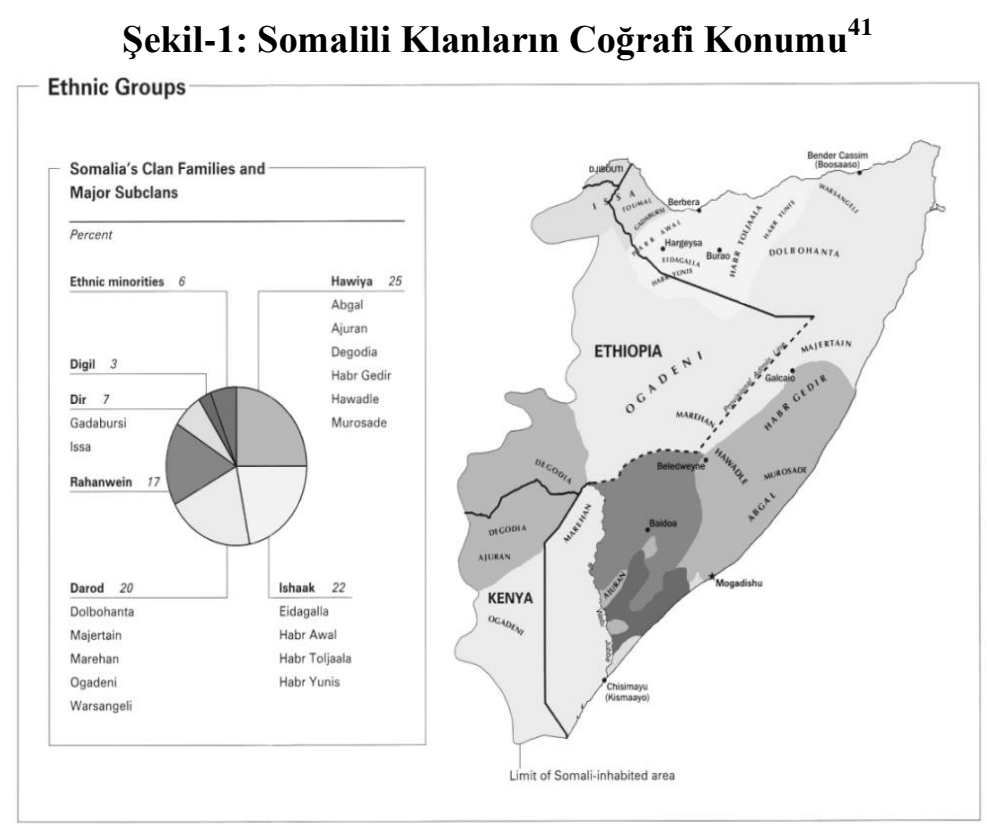

\subsection{Kuraklık, Kutlık ve Su Sorunu}

Kuraklık sorununu yalnızca yağış miktarının azalması olarak görmek yeterli değildir. Yağış miktarının tahmin edilemezliği, düzensizliği, kimi durumlarda da yağışın aşırı artışı da bu sorunsal başlık altında incelenmesi gereken konulardandır. Kuraklık sorununun etkilediği iki ana konu ise içme/kullanma suyu ve gıdadır.

20'nci yüzyılın sonlarında su sorunu dikkatleri çeken konulardan biri haline gelmiştir. 1991 yllında Joyce Starr, Foreign Policy dergisinde $\mathrm{Su}$ Savaşları (Water Wars) başlı̆̆ıyla yayımladığı makalesinde su

${ }^{41}$ Perry-Castañeda Library Map Collection, "Clan Distribution”, University of Texas Libraries, https://legacy.lib.utexas.edu/maps/africa/txu-pclmaps-oclc-795784383somalia_2012.jpg (Erişim Tarihi: 07.06.2020). 
Bölgesel Güvenlik Kompleksi Teorisi Kapsamında

Somali ve Afrika Boynuzu'nun Güvenliği; Aktörler, Tehditler ve Riskler

kıtlığının Kuzey Afrika ve Orta Doğu'da çatışmalara neden olabileceği öngörüsünde bulunmuştur. Hatta daha ileri giderek bu sorunun olas1 trajik sonuçları hakkında istatistik de yayımlamıştır. Bu istatistiklerden biri olan UNICEF (United Nations Children's Emergency Fund-BM Acil Çocuk Fonu) raporlarında her yıl dünya çapında 40 bin çocuk (çoğunluğu Afrika kıtasında) açlıktan veya susuzluktan (yahut da kirli su nedeniyle) ölmektedir. 21'inci yüzyılın başında Afrika nüfusunun yaklaşı \% 40 'ının susuzluk veya kirli su nedeniyle ölüm veya hastalık riski taşıyacağ tahmin edilmektedir. ${ }^{42}$

Dünyanın çeşitli bölgelerinde etkisi görülen kuraklık sorununun kaynaklarından birisi son yüzyıldaki teknolojik gelişmelerle ortaya çıkan iklim değişikliği konusudur. 1992 yılında imzalanan İklim Değişikliğini Konu Alan BM Çerçeve Sözleşmesi'ne (United Nations Framework Convention on Climate Change-UNFCCC) ek, 1997 tarihli Kyoto Protokolü ile yasal bağlayıcılığı olacak şekilde gelişmiş ülkelerin 2012 yılına kadar emisyonu azaltmaları hedeflenmiştir. ${ }^{43}$ İklim Değişikliği Hükûmetlerarası Paneli’nin (Intergovernmental Panel on Climate Change-IPCC) 2007 yll Afrika bulgularına göre, Afrika'daki 1S1 değişimi oranı tüm mevsimlerde küresel ortalamadan daha yüksek olacaktır. ${ }^{44}$ Raporda belirtilen 1 sı ve yağış değişikliğinin, tarıma dayalı ekonomiye sahip Afrika ülkelerinin toplumsal yaşamını ne ölçüde etkileyeceğini şimdiden öngörmek zordur. ABD'nin Afrika Komutanlığı'nın (US African Command-USAFRICOM) görev

\footnotetext{
42 Joyce R. Starr, "Water Wars", Foreign Policy, No. 82 (Spring, 1991), 17-36 82, p. 17-18, https://www.jstor.org/stable/1148639?seq=1\#metadata_info_tab_contents (Erişim Tarihi: 07.06.2020).

${ }^{43}$ James Dobbins et al, Choices for America in a Turbulent World: Strategic Rethink, RAND Corporation, Santa Monica, 2015, p. 81, https://www.rand.org/pubs/research_ reports/RR1114.html (Erişim Tarihi: 07.06.2020).

${ }^{44}$ Jens Hesselbjerg Christensen et al, Regional climate projections, Climate change 2007: The physical science basis, Contribution of Working Group I to the Fourth Assessment Report of the Intergovernmental Panel on Climate Change, 847-940, p. 866, https://www.researchgate.net/publication/284652431_Regional_climate_projections_Clima te_change_2007_The_physical_science_basis (Erişim Tarihi: 07.06.2020).
}

\section{1}

Güvenlik Stratejileri

Cilt: 16

Say1: 36 
892

Güvenlik Stratejileri

Cilt: 16

Sayı: 36

sahalarından birisinin Afrika kıtasının iklim değişikliği etkilerinin değerlendirilmesi ${ }^{45}$ olduğu dikkate alındığında, iklim değişikliği ve bu bağlamda olası kuraklığın küresel güçler tarafindan da takip ediliyor olması konunun önemi hakkında ipucu sunmaktadır.

Kuraklık sorununun Afrika Boynuzu bölgesinde ne ölçüde yaşamı etkileyebileceğini anlayabilmek için 2016 Mart ayında BM'nin Somali'deki İnsani Yardım Koordinatörü (Humanitarian Coordinator) Peter de Clercq'in kuraklıktan kaynaklı açlık nedeniyle bir milyon insanın büyük risk altında olduğu gerekçesiyle uluslararası toplumdan yardım talep etmesi ve gerçekleşmediğinde toplumun aniden çöküşe geçebileceği yönündeki ikazı dikkate değerdir. Hatta BM raporlarında yetersiz beslenme nedeniyle ölümlerin ortaya çıkmaya başladığı da belirtilmektedir. Somali'de özellikle kuzey bölgeleri, Somaliland ve Puntland dâhil, kuraklığa daha çok maruz kalmaktadır. Bu bölgede 385 bin insan acil gıda yardımına muhtaç durumda olup bu miktarın dört katına çıkması söz konusudur. Somali'deki hem çatışmalar hem de kuraklık 1992 yılından öncesinde olduğu gibi, 2010-2012 yıllarında da 250 bin insanın ölümüne neden olmuştur. Kuraklık sadece Somali'yi değil, Etiyopya'yı da yakından etkilemektedir. Son 30 yılın en kurak zamanlarını yaşayan Etiyopya'da da 10,2 milyon insan gıda yardımına muhtaç durumda olup bunların 435 bininin çocuk olması sorunun ciddiyetini göstermektedir. ${ }^{46}$

Afrika'nın Ekvator'a yakın bu bölgesinde Türkiye gibi kuzey kuşaktaki gibi dört mevsim yerine iki mevsim yaşanmaktadır. Bunlar kurak (kuru) mevsim ve yağmurlu mevsimdir. Yağmurlu mevsimde

${ }^{45}$ Kurt M. Campbell et al, The Age of Consequences: The Foreign Policy and National Security Implications of Global Climate Change, Center for Strategic and International Studies (CSIS), ABD, November 2007, p. 20, https://www.researchgate.net/publication/ 235149499_The_Age_of_Consequences_The_Foreign_Policy_and_National_Security_ Implications_of_Global_Climate_Change (Erişim Tarihi: 07.06.2020).

46 Hiiraan Online, "Drought-hit Somalia at 'Tipping Point': UN", 31 March 2016, http://www.hiiraan.com/news4/2016/Mar/104812/drought_hit_somalia_at_tipping_ point_un.aspx (Erişim Tarihi: 07.06.2020). 
bazen gereksinim duyulan yağmur yağmadığından kuraklık görülmekte, bazen de aşırı yağışlar olduğunda sel gelmesiyle toprak ve köyler tahrip olmaktadır. Dolayısıyla dünyanın bu bölgesi yağmurların aşırı azlığı veya çokluğu karşısında doğal afetlerle iç içe yaşamak zorunda kalmaktadır. 2019 Ekim ayı sonlannda UNOCHA (United Nations Office for the Coordination of Humanitarian Affairs-Birleşmiş Milletler İnsani İşler Koordinasyon Ofisi) tarafından yayımlanan rapor, daha önce dile getirilmiş olan aşırı yağışların yol açtığı sellerin de kuraklığın başka bir sorun sahası olduğunu kanıtlar mahiyettedir. "Somali'nin güney bölgesinde yer alan Hiraan Bölgesi'ndeki Belet Weyne şehrinde (Mogadişu'nun kuzeyinde) meydana gelen seller nedeniyle 72 bine yakın insan evini terk etmek zorunda kalmıştır. Ülke, 2011'deki kıtlıktan bu yana en kötü durum ile karşı karşıya kalmış, altı milyon kadar insanın gıda güvencesi olmadığı tahmin edilmektedir. ${ }^{47}$

\section{Afrika Boynuzu ve Uluslararası Aktörler}

Afrika Boynuzu bölgesindeki güvenliği tehdit eden konuları sadece terörizm, kabile/klan, deniz haydutluğu, kuraklık, gıda ve su ile sınırlandırmak yeterli değildir. Bölgede; demokrasiden insan haklarına, ekonomiden eğitime kadar birçok konu yapısal şiddetin kaynağı olarak varlığını sürdürmektedir. Afrika Boynuzu bölgesindeki yapısal sorunları gidermek, öne çıkan güvenlik tehditlerini önlemek için uluslararası aktörler sorumluluk almaktadır. Bölgesel Güvenlik Kompleksi Teorisi kapsamında bölgesel sorunların küresel sisteme zarar vermesi önlenmeye çalışılmaktadır. Kopenhag Okulu tarafindan geliştirilen sektörel güvenlik kapsamında tüm sektörlerde kapsamlı güvenlik yaklaşımı ile sorunlara çözüm aranmalıdır.

47 OCHA, "Somalia: Floods force thousands from their homes", 23 October 2019, https://www.unocha.org/story/somalia-floods-force-thousands-their-homes (Erişim Tarihi: 07.06.2020). 


\section{4}

Güvenlik Stratejileri

Cilt: 16

Sayı: 36

\subsection{Birleşmiş Milletler (BM)}

BM'nin Afrika Boynuzu bölgesindeki rolü, dünyanın diğer bölgelerinde olduğu gibi üst çerçeveyi oluşturmaktır. Bu çerçeve aslında genel olarak Birleşmiş Milletler Güvenlik Konseyi'nin (BMGK) verdiği yetkiyi ifade etmektedir. $\mathrm{Bu}$ bakımdan gerek güvenlik gerek kalkınma gerekse insani yardım maksatlı yürütülen çoğu faaliyet BM'in liderlik ettiği türdendir. BM, küresel tüm aktörlerin (en güçlüden en zayıfa kadar) katılımının sağlandığı en geniş kurum olduğundan, her türlü faaliyetin BM ile ilişkilendirilmesi, BM tarafindan desteklenmesi, BM tarafindan yetkilendirilmesi önemli ve gereklidir. Somali'de görev yapan ve AfB'nin sorumluluğunda icra edilen AMISOM harekâtı BMGK'nin yetkilendirmesi sayesinde yürütülmeye devam etmektedir. BMGK, AMISOM harekâtını belli sürelerle uzatmak suretiyle varlığını ve etkinliğini AfB üzerinde göstermektedir. ${ }^{48}$

BM'nin Afrika kıtasındaki faaliyetlerini yönettiği iki ana merkezi Nairobi (Kenya) ve Addis Ababa (Etiyopya)'dadır. Nairobi'deki ofis BM'nin Afrika'daki ana karargâhıdır. BM'nin Afrika'daki faaliyetlerinin en önemli bölümlerinden birini oluşturan BM barışı koruma harekâtları/misyonları da dokuz ayrı bölgede görevlerini sürdürmektedir. BM'nin halen devam ettirdiği bu dokuz harekât/misyondan Darfur, Abyei ve Güney Sudan; Afrika Boynuzu bölgesinin Sudan ve Güney Sudan bölümünü kapsamaktadır. ${ }^{49}$ Yine yukarıda ifade edildiği gibi BM'nin ana merkezlerinin Nairobi'de ve Addis Ababa'da olduğu dikkate alındığında, BM'nin ilgi sahasına giren bölgelerin başında Doğu Afrika ve Afrika Boynuzu'nun geldiği yorumunda bulunmak şaşırtıcı olmamalıdır.

\subsection{Afrika Birliği (AfB)}

Barış ve güvenlik kavramlarının, ilerleme ve sürdürülebilir kalkınma için gerekli ön koşullar olduğu genel kabul gören bir yaklaşımdır. Bunun

48 The African Union Mission in Somalia (AMISOM) Website, "AMISOM Mandate", https://amisom-au.org/amisom-mandate/ (Erişim Tarihi: 07.06.2020).

${ }^{49}$ United Nations Peacekeeping, "Where We Operate", https://peacekeeping.un.org/ en/where-we-operate (Erişim Tarihi: 07.06.2020). 
Bölgesel Güvenlik Kompleksi Teorisi Kapsamında

Somali ve Afrika Boynuzu'nun Güvenliği; Aktörler, Tehditler ve Riskler

farkında olan Afrikalı devletler bizzat kendi inisiyatifleriyle yakın bölgesel kuruluşlar içinde ve 2000 yılında Togo'da imzaladıkları antlaşmayla kurdukları Afrika Birliği'nin (AfB) liderliği altında çatışmaların önlenmesi ve çözüme kavuşturulması hususunda yoğun gayret sarf etmektedirler.

AfB Kuruluş Antlaşmasında hedefler: "Afrika ülkeleri ve Afrika halkları arasında daha büyük birlik ve dayanışma sağlamak; üye ülkelerin egemenliğini, toprak bütünlüğünü ve bağımsızlıklarını savunmak; kıtanın politik ve sosyo-ekonomik entegrasyonunu hızlandırmak; Afrika'nın ve halklarının çıkarlarına yönelik konularda Afrika'nın ortak pozisyonunu geliştirmek ve savunmak; BM Antlaşması ve İnsan Hakları Evrensel Beyannamesi'ni dikkate alarak uluslararası iş birliğini güçlendirmek; kıtada barış, güvenlik ve istikrarı geliştirmek" ${ }^{50}$ olarak belirlenmiştir. Birliğin kuruluş amacı, Afrika ülkeleri arasındaki birliğin tesisi, Afrika'daki halkların yaşam standartlarının yükseltilmesi ve kıta genelinde her türlü sömürgeciliğin kaldırılması olarak özetlenebilmektedir. ${ }^{51}$

Bunun sonucu olarak AfB çatışmaları önleme ve çözme konusunda liderliği almış, bu maksatla Afrika'nın bölgesel yapılarını da içerecek şekilde Afrika Barış ve Güvenlik Mimarisi'ni (African Peace and Security Architecture-APSA) oluşturmuştur. Bunun önemli bir göstergesi Somali'de (AMISOM) gerçekleştirdiği BDH'lerdir. APSA, bir çerçeve çalışmayı ifade ederken, içeriğinde hukuksal antlaşmalar, çeşitli kurumlar, karar verme süreçleri vardır. APSA'nın temel bileşenleri olarak AfB Barış ve Güvenlik Konseyi (Peace and Security CouncilPSC), Akiller Heyeti (Panel of the Wise), Afrika Müdahale Kuvveti (African Standby Force-ASF), Afrika Barış Fonu (African Peace Fund) ve Kitasal Erken Uyarı Sistemi (Continental Early Warning System) sayılmaktadır. PSC, merkezî karar verme organıdır ve AfB'nin ana

\footnotetext{
${ }^{50}$ African Union Website, "Constitutive Act of the African Union", https://au.int/sites/ default/files/pages/34873-file-constitutiveact_en.pdf (Erişim Tarihi: 07.06.2020).

${ }^{51}$ Soner Karagül ve İbrahim Arslan, "Afrika'da Barış ve Güvenliğin İnşasında Kıtasal Yaklaşım: Afrika Barış ve Güvenlik Mimarisi”, Güvenlik Stratejileri Dergisi, 2014, s. 19, 57-98, s. 63.
}

\section{5}

Güvenlik Stratejileri

Cilt: 16

Say1: 36 
896

Güvenlik Stratejileri

Cilt: 16

Sayı: 36

karargâhının bulunduğu Etiyopya'nın başkenti Addis Ababa'dadır. PSC, AfB nezdinde ve güvenlik konularında özellikle $A B$ ile yakın iş birliği içinde çalışmaktadır.

AfB barış ve güvenlik kapsamında kıtaya yayılmış bulunan sekiz adet Bölgesel Ekonomik Topluluk (Regional Economic Community-REC) ile yakın temas içinde çalıșmaktadır. Bu örgütlerden biri olan Kalkınma İçin Hükûmetleraras1 Otorite (Inter-Governmental Authority for Development-IGAD) isimli 1996 yılında kurulan ve Doğu Afrika'nın (Afrika Boynuzu bölgesi dâhil) kalkınmasını esas alan örgüte Sudan, Güney Sudan, Etiyopya, Kenya, Uganda, Eritre, Somali ve Cibuti üyedir.

\subsection{Avrupa Birliği (AB)}

Avrupa ve Afrika kıtasındaki ülkeler çok çeşitli alanlarda yakın iş birliği yapmakta, $\mathrm{AB}$ ile Afrika Birliği arasındaki iş birliği barış ve güvenlik temelinde gelişme göstermektedir. Ancak $A B$ 'nin genel olarak rolünün destekleyen yani "veren", AfB'nin ve Afrika ülkelerinin de genel olarak rolünün desteklenen yani "alan" durumunda olması, bu iş birliğinin eşit olmayan koşullarda yürütülmediği sonucunu doğurmaktadır.

AB ile Afrika arasındaki mevcut ilişki genel olarak; ekonomik, politik ve kalkınma iş birliği programları ile Afrika'nın desteklenmesi şeklinde özetlenebilir. AB ile Afrika kıtası arasındaki ilişkilerin çerçevesini oluşturan ana kaynaklardan birisi 2000 y1lında kabul edilen Cotonou $^{52}$ Antlaşmas1; 1975 tarihli Afrika, Karayipler ve Pasifik ülkelerini kapsayan Lome $^{53}$ Antlaşmasını (Convention) değiştiren antlaşmadır. AB ile Afrika arasında ilk zirve 2000 yllında Kahire'de gerçekleștirilmiștir. Kısa süre sonra da Afrika Birliği Örgütü (Organisation of African Unity-OAU), $\mathrm{AB}$ benzeri bir yapılanmayla Afrika Birliği (African Union-AU) halini almıştır. 2007 yılında ise Lizbon'da kabul edilen Müşterek Afrika-AB Stratejisi (Joint Africa-EU Strategy-JAES) tamamlayıcı bir çerçeve olarak ilişkilerin yürütülmesinde resmî bir

${ }^{52}$ Cotonou, Batı Afrika ülkesi Benin'in başkentidir.

${ }^{53}$ Lome, Batı Afrika ülkesi Togo'nun başkentidir. 
Bölgesel Güvenlik Kompleksi Teorisi Kapsamında

Somali ve Afrika Boynuzu'nun Güvenliği; Aktörler, Tehditler ve Riskler

kanal oluşturmuştur. ${ }^{54}$ JAES'e göre "barış ve güvenlik" konusu AfrikaAB Barış ve Güvenlik Ortaklığı (Africa-EU Peace and Security Partnership) adıyla iş birliğinin öncelikli sekiz alanından ${ }^{55}$ biri olarak belirlenmiştir. İş birliğinin temel alanlarından biri, Afrika Barış ve Güvenlik Mimarisinin (African Peace and Security ArchitectureAPSA) tam harekât yeteneğine kavuşturulmasıdır. JAES, Eylem Planları vasitasıyla hayata geçirilmektedir. JAES ve onu takip eden Eylem Planları, APSA'nın Afrika Barış Kapasitesi (African Peace FacilityAPF) ile destekleneceğini teyit etmiştir. ${ }^{56}$

$\mathrm{AB}$ ile Afrika arasındaki barış ve güvenlik iş birliğinin temel araçlarından öne çıkanlar Afrika Barış Vasıtası (African Peace FacilityAPF) ve Ortak Güvenlik ve Savunma Politikası (Common Security and Defense Policy-CSDP) misyon/harekâtlarıdır. AB'nin Afrika dâhil, bölgesel veya küresel tüm ilişkileri Avrupa Dış Faaliyetler Servisi (European External Action Service-EEAS) tarafindan yönetilmektedir. EEAS'in başında AB Dış İlişkiler ve Güvenlik Politikaları Yüksek Temsilcisi (High Representative for Foreign Affairs and Security Policy) bulunmaktadır. EEAS resmî olarak 01 Ocak 2011 tarihinde 2009 y1lında yürürlüğe giren Lizbon Antlaşması sonrasında görevine başlamıştır. ${ }^{57}$ EEAS'de Afrika Direktörlügü görevini yürüten personelin

54 İbrahim Arslan, "21. Yüzyılda Afrika-Avrupa Birliği İlişkileri: İki Birlik, Tek Vizyon”, Marmara Avrupa Araştırmaları Dergisi, 2015, Sayı 1, 109-135, s. 118.

55 JAES' in 2007 yılında kabul edilen ilk dokümanında öncelikli konular farklı sınıflandırma ve ifadelerle belirtilmiştir. JAES'in gereği olarak hazırlanan 2008-2010 ve 2011-2013 Eylem Planlarında öncelikli konular sekiz olarak belirlenmiştir. Öncelikli sekiz konu şunlardır: (1) Barış ve Güvenlik; (2) Demokratik Hükûmet ve İnsan Hakları; (3) Bölgesel Ekonomik Entegrasyon, Ticaret ve Altyapı; (4) Milenyum Kalkınma Hedefleri; (5) İklim Değiş̧ikliği; (6) Enerji; (7) Göçler, Yer Değiştirmeler ve İstihdam; (8) Bilim, Bilgi Toplumu ve Uzay. Council of the European Union, The Africa-EU Strategic Partnership-A Joint Africa-EU Strategy, Lisbon, 9 December 2007, https://www.consilium.europa.eu/uedocs/ cms_data/docs/pressdata/en/er/97496.pdf (Erişim Tarihi: 08.06.2020).

${ }^{56}$ European Council and Council of the European Union Website, "EU-Africa Relations", http://www.consilium.europa.eu/en/policies/eu-africa (Erişim Tarihi: 08.06.2020).

57 European Union Website, "About the European External Action Service (EEAS)", https://eeas.europa.eu/headquarters/headquarters-homepage/82/about-european-external - 
898

Güvenlik Stratejileri

Cilt: 16

Sayı: 36

daha önce Afrika'da görev yapmış deneyimli personelden seçildiği görülmektedir. Örneğin Belçikalı diplomat Koen Vervaeke, bu görev öncesinde Afrika Direktörlüğü altında yer alan Afrika Boynuzu, Doğu ve Güney Afrika ile Hint Okyanusu Bölge Direktörlüğü görevini yürütmüştür. Daha öncesinde de Addis Ababa'da AB'nin AfB Temsil Heyeti Başkanlığ görevini icra etmiş bulunmaktadır. ${ }^{58} \mathrm{AB}$ 'nin personel seçiminde dikkate almaya çalıştığı gibi, bölge hakkında yeterli bilgiye, birikim ve deneyime sahip olma önemlidir.

Daha önce bahsi geçen APF (African Peace Facility-Afrika Barış Vasıtası), AB ile Afrika arasında barış ve güvenlik konularındaki iş birliğinin temel finansal aracı olarak önemlidir. APF, Afrikalı liderlerin 2003 yılında yapılan AfB Maputo Zirvesindeki talepleri sonrasında 2004 yılında oluşturulmuştur. APF vasıtası ile AB uzun vadeli bir projeksiyonla APSA'nın uluslararası boyuttaki desteği konusunda kendini en öndeki safta bulmuştur. Daha somut bir ifadeyle, AB'nin bu vasıtay1 kullanarak Afrika'ya sağlamayı vadettiği politik destek yanında; Afrika Birliği liderliğinde icra edilen Barışı Destekleme Harekâtlarına (BDH) finansal destek, APSA'ya harekât yeteneği ve kapasite oluşturma/geliştirme desteği kazandırılması, Erken Uyarı Mekanizmas1 (Early Response Mechanism-ERM) inisiyatifine destek ve kıtasal / bölgesel bazda arabuluculuk desteği olarak belirlenmiştir. ${ }^{59}$

$\mathrm{AB}$ ile Afrika/AfB arasındaki ilişkiler ağını anlamada CSDP'nin de önemli rolü bulunmaktadır. CSDP, AB'nin BDH'lerde, çatışmaları önleme hususunda ve uluslararası güvenliği güçlendirme konusunda lider rol üstlenmesini sağlayabilmesi maksadıyla geliştirdiği politikadır. ${ }^{60}$

action-service-eeas en (Erişim Tarihi: 09.06.2020).

${ }^{58}$ European External Action Service Website (EEAS), "HQ Organisation Chart", 1 October 2020, https://eeas.europa.eu/sites/eeas/files/2020-01-10-eeas_2.0_orgchart.pdf (Erişim Tarihi: 23.11.2020).

59 European Commission, African Peace Facility Annual Report 2014, 2015, p. 5, https://africa-eu-partnership.org/sites/default/files/documents/african_peace_facility_ annual_report_2014_en.pdf (Erişim Tarihi: 09.06.2020).

${ }^{60}$ European External Action Service Website (EEAS), "The Common Security and Defence Policy (CSDP)", https://eeas.europa.eu/topics/common-security-and-defence- 
CSDP ile AB'ye üye ülkeler tarafından oluşturulan kaynak havuzu, daha hızlı ve daha etkili faaliyet gösterebilen savunma yeteneğine de kavuşturulmuş olmaktadır. ${ }^{61} \mathrm{Bu}$ bağlamda AB'nin Ekim 2015 tarihi itibariyle 8'i Afrika'da tamamlanmış ve halen 8'i Afrika'da devam eden askerî ve sivil harekâtları/misyonları mevcuttur. AB'nin doğu Afrika özelinde tamamlamış bulunduğu Güney Sudan'daki EUAVSEC Misyonu (European Union Aviation Security Mission-AB Uçuş Güvenliği Misyonu / 2012-2014); halen devam eden Somali'deki EUTM (EU Training Mission-AB Eğitim Misyon /2010-); Cibuti, Somali, Seyşeller ve Tanzanya'yı kapsayan EUCAP Somalia Misyonu (EU's Capacity Building Effort in the Horn of Africa and the Western Indian OceanAB'nin Afrika Boynuzunda ve Batı Hint Okyanusunda Kapasite Oluşturma Gayretleri/2012-) ve deniz güvenliği bağlamında Somali bölgesinde EU NAVFOR ATALANTA Harekâtı (EU Navy Force ATALANTA-AB Deniz Gücü ATALANTA/ 2008-) bulunmaktadır.

Askerî bakımdan bir sivil misyon veya askerî harekât anlamına gelen CSDP'nin Afrika bağlamında amaçları şu şekildedir:

- Geçici süreyle destek sağlayarak bölgenin Afrikalı ortaklara devredilmeden önce güvenli hale getirilmesini sağlamak. Bu, mevcut uluslararası çabalara destek sağlamak için bölgede risk altında yaşayan nüfusu korumak, insani gereksinim içinde bulunan topluluklara yardımın ulaşmasını sağlamak gibi faaliyetleri içermektedir.

- Sivil veya askerî otoritelere, ordunun yeniden teşkilinde (Security Sector Reform-Güvenlik Sektörü Reformu) danışmanlık sağlamak. Böylece güvenliğin tüm ülkede var olması garanti edilecek, ekonomik ve sosyal kalkınmanın mümkün olması için gereken koşullar yeniden yaratılmış olacaktır.

policy-csdp_en (Erişim Tarihi: 09.06.2020).

${ }^{61}$ European External Action Service Website (EEAS), "Military and Civilian Missions and Operations",

(Erişim Tarihi: 08.06.2020).

\section{9}

Güvenlik Stratejileri

Cilt: 16

Say1: 36 
900

Güvenlik Stratejileri

Cilt: 16

Sayı: 36

- Silahlı kuvvetlerin yeniden oluşturulması için eğitim vermek ve bu faaliyetleri desteklemek. Bu maksatla da uzmanlık desteği vermek ve tavsiyelerde bulunmak önemli görülmektedir. Özellikle komuta ve kontrol, lojistik zincir, insan kaynakları ve uluslararası hukuk konularında uzmanlık desteği ve tavsiyede bulunmaya öncelik verilmektedir.

2014 yılı AB açısından Afrika kıtasında Somali, Orta Afrika Cumhuriyeti ve Mali'de yürütülen $\mathrm{BDH}$ bağlamında oldukça aktif geçmiş, 2015 yılında ve günümüzde de bu aktif yaklaşım devam etmektedir. AB, APF vasitasiyla Somali'de bulunan AfB AMISOM harekâtını artan oranda finansal olarak desteklemeye devam etmektedir. Bu oran 2014 y1lı için 225 milyon Avro düzeyinde gerçekleşmiștir. ${ }^{62}$ AB'nin AMISOM'a bugüne kadar sağladığı toplam destek ise 580 milyon Avro'dan fazladır. ${ }^{63}$

Yukarıda anlatılan hususlar ışığında, AB'nin Somali ve daha geniş olarak da Afrika Boynuzu bölgesi ülkeleriyle olan barış ve güvenlik kapsamlı ilişkileri incelendiğinde; AB'nin, Somali ve Afrika Boynuzunda faaliyetlerini kapsamlı yaklaşımla ele aldığı görülmektedir. Buna göre de aktif bir diploması ile özellikle Somali'ye politik destek, güvenlik desteği, kalkınma yardımı ve insani yardım sağlamaktadır. AB'nin çeşitli faaliyetlerle Somali'ye sağlamış olduğu kaynak yıllar içinde 1 milyar Avro'yu geçmiştir.

AB'nin Somali merkezli olarak yürüttüğü EUTM Misyonu, 01 Nisan 2010 tarihinde Somali'nin desteklenmesi amacıyla yürürlüğe

${ }^{62}$ AMISOM'un askerî kuvvetine katkı sağlayan ülkeler Burundi, Cibuti, Etiyopya, Kenya ve Uganda'dır. Polis kuvvetine katkı sağlayan ülkeler ise Gana, Kenya, Nijerya, Sierra Leone, Uganda ve Zambiya'dır. The African Union Mission in Somalia (AMISOM) Website, “AMISOM Background”, https://amisom-au.org/amisombackground/ (Erişim Tarihi: 08.06.2020).

${ }^{63}$ European External Action Service Website (EEAS), "Common Security And Defence Policy European Union Training Mission - Somalia", http://www.eeas.europa.eu/archives/ docs/csdp/missions-and-operations/eutm-somalia/docs/factsheet_eutm_somalia_en.pdf (Erişim Tarihi: 08.06.2020). 

yapmakta olup, bütçesi 8,9 milyon Avro'dur. Misyona katkı sağlayan 11 ülke: Almanya, İspanya, Finlandiya, Fransa, Macaristan, İtalya, Hollanda, Portekiz, Romanya, İsveç ve İngiltere'dir. Üçüncü ülkelerden de Sırbistan katkı sağlamaktadır. EUTM'in başlangıçtaki maksadı Federal Geçiş Hükûmeti'nin (Transitional Federal Government-TFG) ${ }^{64}$ ve kurumlarının güçlendirilmesine katkı sağlamaktı. EUTM ile AB'nin Somali Savunma Bakanlı̆̆ı'na ve Somali Silahlı Kuvvetleri'ne (SNF) sağladığı eğitim desteği; Somali askerî eğitim sistemi çerçevesinde olarak "temel eğitim", "liderlik eğitimi", "özel ihtisas gerektiren askerî konularda eğitim" ve "danışmanlık" konulanılır. EUTM ayrıca güvenlik bölgeleri oluşturma, personel yönetimi, stratejik planlama ve savunma kapsamında hukukî mevzuat konularında stratejik danışmanlık sağlamaktadır. ${ }^{65}$

EUTM misyonunun tamamlayıcisı iki misyon olan EU NAVFOR ATALANTA ile Aden Körfezinde deniz haydutluğu ile mücadeleye katk1 devam ederken, EUCAP Somalia ile de Afrika Boynuzunda (Horn of Africa-HoA) ve Batı Hint Okyanusu (West Indian OceanWIO) bölgesinde deniz güvenliği için kapasite geliştirme faaliyetleri devam etmektedir. EUTM eğitim timleri, Somali'de görev yapmakta olan AfB'ne bağlı AMISOM ve BM'ye bağlı UNSOM (UN Assistance Mission in Somalia-BM Somali Yardım Misyonu) ile yakın irtibat halinde görevini yapmaktadır.

EU NAVFOR ATALANTA, Somali merkezli olarak Afrika Boynuzunda ve Batı Hint Okyanusunda baş gösteren deniz haydutluğu ve silahlı soygunlardan duyduğu endişe sonrasında, Somali'ye kapsamlı yaklaşımın bir parçası olarak başlattığı bir harekâttır. EU NAVFOR ATALANTA, Aralık 2008'de CSDP çerçevesinde, BM Güvenlik Konseyi kararları ve uluslararası hukuk kurallarına uyumlu şekilde

\footnotetext{
${ }^{64}$ Şimdiki adıyla Somali Federal Hükûmeti'dir.

${ }^{65}$ European Council and Council of the European Union Website, "Somalia: EU Extends Training Mission”, https:/www.consilium.europa.eu/en/press/press-releases/2015/03/16/ eutm-somalia-training-mission/ (Erişim Tarihi: 09.06.2020).
}

\section{1}

Güvenlik Stratejileri

Cilt: 16

Say1: 36 

Security Center-Horn of Africa/MSCHOA) tarafindan bu bölgeye ait Yüksek Risk Alanları (High Risk Areas) belirlenmiştir. AB üyesi ülkelerin ticaret hacminin \%95'inin deniz yoluyla yapıldığ1, dünya ticaret hacminin \%20'sinin ise Aden Körfezinden yapıldı $\breve{g}_{1}{ }^{67}$ dikkate alındığında bu bölgedeki deniz güvenliğinin $\mathrm{AB}$ açısından ne denli önemli olduğu açıkça görülmektedir. EU NAVFOR ATALANTA bölgede deniz güvenliği konusunda faaliyet gösteren diğer ülke ve NATO (Operation Ocean Shield-Okyanus Kalkanı Harekâtı) başta olmak üzere uluslararası kuruluşlarla da yakın ilişki ve koordinasyon içinde olmaya gayret göstermektedir.

EUCAP Somalia, daha önce de ifade edildiği gibi Afrika Boynuzunda ve Batı Hint Okyanusu bölgesinde deniz güvenliği için kapasite geliştirme faaliyetlerine devam eden, CSDP altında faaliyet gösteren sivil ve silah gücü bulunmayan bir misyondur. EUCAP Somalia misyonu AB tarafindan 16 Temmuz 2012'de oluşturulmuş, 10 Eylül 2012 tarihinde ise fiilen görevine başlamıştır. Misyonun amac1; bölgede bulunan ev sahibi ülkelerin, deniz haydutluğu ile mücadele ve deniz yönetimi dâhil deniz güvenliği konularında kendine yeterli bir kapasiteye ulaşmalarına destek olmaktır. Misyon 2016'nın başından itibaren Seyşeller ve Cibuti'deki faaliyetlerini sonlandırarak çabalarını sadece Somali'ye (Somaliland dâhil) yoğunlaştırmıştır. ${ }^{68}$

\subsection{NATO}

NATO ile Afrika arasındaki ilişki ve etkileşim daha çok AfB üzerinden, bazen de doğrudan Afrika kıtasındaki ülkelerle "barış ve güvenlik" kapsamında, kısmen de "ortaklık ve iş birliği" ile sınırlı

66 EU Naval Force-Somalia Operation ATALANTA Website, "Mission", https://eunavfor.eu/mission/ (Erişim Tarihi: 09.06.2020).

67 EU Naval Force-Somalia Operation ATALANTA Website, "MSCHOA", https://eunavfor.eu/mschoa/ (Erişim Tarihi: 09.06.2020).

${ }^{68}$ EUCAP Somalia Website, "Mission Background", https://www.eucap-som.eu/ about-us/ Erișim Tarihi: 18 Aralık 2015. 
düzeyde yürütülmektedir. Yukarıda $\mathrm{AB}$ ve Afrika arasında geliştirilen politik, ekonomik, güvenlik ve sosyo-kültürel olarak geliştirilen karmaşık ve iç içe geçmiş ilişkiler ile karşılaştırıldığında, NATO'nun Afrika stratejisinin sade ve sembolik olduğu görülmektedir.

NATO'nun Afrika ile ilişkilerine yön veren harekâtı Afrika Boynuzu ve Batı Hint Okyanusu bölgesinde icra etmekte olduğu Okyanus Kalkanı Harekâtı (Operation Ocean Shield-OOS)'dır. NATO'nun Okyanus Kalkanı Harekâtı Ağustos 2009 tarihinde başlamış olup 2016 sonuna kadar devam etmesine karar verilmiş bulunmaktadır. NATO bu harekât1; AB'nin NAVFOR ATALANTA, ABD'nin Birleşik Görev Kuvveti-151 (Combined Task Force-CTF-151) ve bölgede benzer görevler yapan müstakil ülkelerle uyum ve yakın iş birliği içinde yürütmektedir. Bir başarı göstergesi olarak Mayıs 2012'den beri bölgede herhangi bir deniz haydutluğu olayı meydana gelmemiştir. ${ }^{69}$ Türkiye de, BMGK'nın en son 2184 sayılı kararı çerçevesinde, deniz haydutluğu ve silahlı soygun eylemleriyle mücadele amaciyla yürütülen uluslararası çabalara destek vermek üzere, Türk Silahlı Kuvvetleri deniz unsurlarını dost ve müttefik ülke deniz kuvvetleri ile birlikte Aden Körfezi, Somali karasuları ve açıkları ile mücavir bölgelerde görevlendirmiştir. Türkiye bölgedeki faaliyetlere, NATO Okyanus Kalkanı Harekâtı ve Birleşik Görev Kuvveti-151 (CTF-151) kapsamında gemi görevlendirerek katk1 sağlamaktadır. ${ }^{70}$

Afrika Boynuzu gibi bölgesel harekât ve ortaklık/iş birliği faaliyetleri önemli olmakla birlikte, NATO'nun Afrika stratejisini NATO'nun AfB ile ilişkileri bağlamında ele almanın daha gerçekçi olduğu düşünülmektedir. Zira NATO'nun Afrika ile ilişkileri temelde AfB kanalıyla yürütülmektedir. ${ }^{71}$

\footnotetext{
${ }^{69}$ North Atlantic Treaty Organization Website, "NATO and the Republic of Djibouti consolidate their cooperation", www.nato.int/cps/en/natohq/news_118880.htm (Erişim Tarihi: 07.06.2020).

${ }^{70}$ TSK Gnkur. Bşk.lığı Resmî Sitesi, “Türkiye'nin Barışı Destekleme Harekâtına Katkıları”, https://www.tsk.tr/Sayfalar?viewName=BarisiDestekleme (Erişim Tarihi: 22.11.2020).

${ }^{71}$ North Atlantic Treaty Organization Website, "Cooperation with the African Union",
}

\section{3}

Güvenlik Stratejileri

Cilt: 16

Say1: 36 


\section{4}

Güvenlik Stratejileri

Cilt: 16

Sayı: 36

\subsection{Türkiye}

Dünyada hem politik hem de ekonomik düzlemde güç dengelerinin yer değiştirmeye ve yeni bir dünya düzeninin ana hatlarının belirmeye başladığı bir süreçte Türkiye, firsatlarla tehditlerin iç içe geçtiği bu dönemde değişimin odağında bulunan ülkelerden biridir. Bu kapsamda Türkiye'nin çok boyutlu dış politikasının stratejik faaliyet alanlarından birini Afrika kıtasıyla ilişkiler oluşturmaktadır.

Türkiye ile Afrika arasında en önemli kilometre taşı olan 2008 yılındaki Afrika Birliği Zirvesi’nde Türkiye'nin kıtanın stratejik ortağı ilan edilmesiyle ve aynı yıl Türkiye-Afrika İşbirliği Zirvesi’nin düzenlenmesiyle güçlenen ilişkiler, 2010 y1lında Afrika'ya yönelik politikanın esaslarını içeren "Afrika Strateji Belgesi”nin yürürlüğe girmesiyle yeni bir hız ve içerik kazanmıştır. 2013 yılı itibariyle “Afrika'ya Açılım Politikası" yerini "Afrika Ortaklık Politikası"na bırakmıştır. Türkiye, Ortaklık Politikasıyla kıtanın barış ve istikrarı ile ekonomik ve sosyal kalkınmasına katkıda bulunmayı, ayrıca ikili ilişkilerde "eşit ortaklık" ve "karşılıklı fayda" temelinde geliştirmeyi hedeflemektedir. 19-21 Kasim 2014 tarihlerinde Ekvator Ginesi'nin başkenti Malabo'da düzenlenen II. Türkiye-Afrika Ortaklık Zirvesi'nde ilişkileri daha da ileriye götürmeye yönelik yol haritası belirlenmiştir. Sayın T.C. Cumhurbaşkanının katıldığı, Afrika'dan 30'a yakın ülkenin temsil edildiği zirve, katılım bakımından emsallerini geride bırakmıştır. ${ }^{72}$

Türkiye'nin Afrika'ya yönelik politikalarında Somali'nin pilot bir konumu vardır. Türkiye'nin Afrika'da izlediği insani diplomasi odaklı dış politikasının en güzel örneği bu ülkede kendini göstermektedir. Somali'ye kapsamlı yardım faaliyetleri hız kaybetmeden devam etmekte olup, bu çerçevede, başkent Mogadişu merkezli olarak altyapı, eğitim ve sağlık alanlarında çalışmalar yapılmaktadır. Mogadişu dışında başta

16 November 2020, https://www.nato.int/cps/en/natohq/topics_8191.htm (Erişim Tarihi: 22.11.2020).

${ }^{72}$ Türkiye Cumhuriyeti Dışişleri Bakanlığı, "2015 Y1lına Girerken Dış Politikamız”, s. 107, http://www.mfa.gov.tr/site_media/html/2015-yilina-girerken-dis-politikamiz.pdf (Erişim Tarihi: 07.06.2020). 
bölgesel başkentler olmak üzere Somali'nin tüm bölgelerinde eğitim ve sağlık alanında çalışmalar planlanmaktadır. Mogadişu'da inşa edilen ve açılışı 2015 yılında yapılan 200 yatak kapasiteli Somali Mogadişu Türkiye Recep Tayyip Erdoğan Eğitim ve Araştırma Hastanesi sadece bölgenin değil Afrika'nın en modern sağlık tesislerinden biri olup, Türk halkının gönülden yaptığı yardımlarla Somali'de hayata geçirilen çok sayıdaki sağlık projesinden yalnızca birisidir. ${ }^{73}$

Somali Silahlı Kuvvetlerinin yeniden yapılandırılması amacıyla TSK Genelkurmay Başkanlığı tarafından gerekli planlama ve stratejik hazırlıklar yapılmış, bu kapsamda içinde Subay ve Astsubay Okulu ile Eğitim Merkezi bulunan Somali Türk Görev Kuvvet Komutanlığı (STGK K.lı̆ğ 30 Eylül 2017 tarihinde Mogadişu'da açılmıştır. ${ }^{74}$ Somali güvenlik güçlerinin Türkiye'de eğitimlerine ise devam edilmektedir. $\mathrm{Bu}$ amaçla 2013-2014 döneminde 120 subay ve astsubayın eğitimleri tamamlanmış; 2014-2015 döneminde de 140 subay ve astsubaya eğitim verilmesi planlanmıştır. Öte yandan, Mogadişu Limanı ve Havalimanı'nın işletmeleri Türk şirketleri tarafindan üstlenilmiştir. Türkiye, Somali'ye yönelik uluslararası yardım çabaları bağlamında da öncü bir rol oynamakta, kurulan mekanizmaların yönetiminde yer almakta ve bunları yönlendirmektedir. Türkiye'nin Afrika'ya artan ilgisinin en somut göstergesi olan Somali'deki başarılara güvenlik ortamının gölge düşürmesine izin verilmemesi önemlidir. Türkiye'nin Afrika kıtası ile ilişkilerinde temel aldığ yaklaşım "insani diplomasi" (humanitarian diplomacy) konusuna odaklanmıştır.

\subsection{Amerika Birleşik Devletleri (ABD)}

ABD'nin 2007'de kurduğu USAFRICOM'un' ${ }^{75}$ ana karargâh1 Almanya'da (Stuttgart) olmakla birlikte ileri üs görevleri için Cibuti'de bir üs teşkil etmiştir. ABD'nin Afrika'daki tek yerleşik üssü olan “Camp

\footnotetext{
${ }^{73}$ A.g.e., s. 111 (Erişim Tarihi: 07.06.2020).

${ }^{74}$ Güngör Şahin (Ed.), a.g.e., s. 117.

75 Oktay Bingöl, “ABD Ulusal Güvenlik Stratejisinin Küresel Uygulayıcıları: Coğrafi Muharip Komutanlıklar”, Güvenlik Stratejileri Dergisi, 2014, Sayı: 19,133-166, s. 136.
}

\section{5}

Güvenlik Stratejileri

Cilt: 16

Say1: 36 
Lemonnier" $\mathrm{i}$ (Lemonnier Üssü) ${ }^{76}$ kullanma iznini 2015 yılında yaptı̆g 1 antlaşmayla 20 yıl daha uzatmıştır.

ABD'nin Afrika Boynuzu bölgesinde aktif politik ve askerî varlık göstermesinin merkezinde Cibuti, Somali ve belli ölçüde de Etiyopya olduğu görülmektedir. $\mathrm{ABD}$, Somali güçlerine ve aynı zamanda AMISOM güçlerine destek sağlamaktadır. ABD yönetiminin uyguladığı strateji gereği, ABD askerleri arazide doğrudan çatışmak yerine, Somali ve AMISOM güçlerinin teşkilatlanması, donatılması ve danışmanlık sağlanmasında rol almaktadırlar. ABD, diğer birçok ülkede icra etmekte olduğu politikalarına benzer şekilde, askerî yönden desteklediği ülke ve bölgelerin kalkınmasında da rol oynamaya özen göstermektedir. Böylece insan yaşamına mal olan operasyonların toplumsal hoşnutsuzluğunu azaltmak ve dönüştürmek için çaba sarfetmektedir. AFRICOM'un Cibuti'de konuşlu Afrika Boynuzu Birleşik Müşterek Görev Kuvveti (Horn of Africa Combined Joint Task Force-HoA CJTF), bölgedeki terörizm ile mücadelenin ve yerel güçleri eğitmenin esas gücü olarak görev yapmaktadır.

\section{Sonuç}

Afrika kıtası son yıllarda yeniden keşfedilmeye ve dünyanın ilgisini çekmeye başlamıştır. Bu kıtaya ilgisiz kalmak firsatları kaçırmaya neden olabilecektir. Somali ve Afrika Boynuzu özelinde bölgesel istikrarsızlık, göç ve sığınmacılar, kuraklık ve su sorunu, El-Şebab kaynaklı terör ve küresel ekonominin ana arterlerinden olan Aden Körfezi bölgesindeki güvenlik sorunları göz ardı edilemeyecek özelliktedir. Riskin bir boyutu da anılan bu sorunların kıta dışına taşması durumunda dünyadaki yansımalarının öngörülememe ve yeterli tedbir alınamama endişesinden kaynaklanmaktadır. Bu sebeple BM, AfB, AB, Türkiye

76 "Camp Lemonnier" (Lemonnier Üssü), Cibuti Ambouli Uluslararası Havaalanı bölgesinde, ABD'nin Afrika Komutanlığı'nın (U.S. Africa Command - USAFRICOM) "Birleşik Müşterek Görev Kuvveti - Afrika Boynuzu" (Combined Joint Task Force - Horn of Africa / CJTF-HOA) birliklerinin konuşlu olduğu üs'tür. Wikipedia, "Camp Lemonnier", https://en.wikipedia.org/wiki/Camp_Lemonnier (Erişim Tarihi: 06.06.2020). 
ve ABD gibi aktörler; güvenlik sorunlarını engellemek amacıyla çeşitli mekanizmalar ve stratejiler geliştirmiş, kapsamlı bir yaklaşımla siyasi ve güvenlik konularının yanına kalkınma endeksli ekonomik, sosyal ve kültürel konuları da geliştirilen stratejilerinin bir parçası olarak eklemişlerdir.

Bölgesel Güvenlik Kompleksi Teorisi kapsamında değerlendirildiğinde, Somali'yi merkeze alarak incelenen Afrika Boynuzu bölgesindeki güvenlik sorunlarının tarihsel, kültürel, etnik, sosyoekonomik, siyasi ve askerî temelleri bulunmaktadır. Bu temelden beslenen dostluk-düşmanlık algılamaları, aynı bölgeyi paylaşan devletler arasındaki iş birliği yerine çatışma dinamiklerini tetiklemektedir. Bölgede son otuz yıldır yaşanan ve çözülemeyen sorunlar karşısında günümüzde bölgenin bu birikmiş sorunlarına kısa sürede ve kalıcı çözümler sunabilmek hiç de kolay değildir. Her ne kadar Afrika kıtası ve bu bölge göz alıcı bir doğaya, genç insan gücüne, zengin doğal kaynaklara sahip gözükse de eğitimden altyapıya, ekonomiden siyasi iş birliğine kadar çok çeşitli konularda henüz yeterince ilerleme sağlanamamıştır.

Somali başta olmak üzere bölge ülkelerinin "kendilerine ve kaynaklarına güvenmeleri” gerçek kalıcı barışın olmazsa olmazıdır. Afrika Boynuzu bölgesindeki ülkelerin kendi aralarında, hatta Somali örneğinde görüldüğü gibi ülke içindeki kabileler arasında birlik, beraberlik ve dayanışmanın yeterince sağlanamamış olması da terörizme taban sağlamaktadır. El-Şebab Terör Örgütü de bu bölgenin kendi kabuğunu kırmasına ve sorunlarının üstesinden gelmelerine engel bir "endişe ve korku" kaynağı olmaya devam etmektedir. El-Şebab'a yönelik risk/tehdit algısının şimdilik küresel olmaktan çok bölgesel ve belli ölçüde Afrika kıtası kapsamında kaldığ1 görülmektedir. Diğer taraftan Somali, Aden Körfezi veya Afrika Boynuzu; "deniz haydutluğu" ile de anılmakta, deniz güvenliği tedbirleri gevşetildiğinde sorunun tekrarlanma riski bulunmaktadır. Afrika Boynuzu bölgesindeki sorunların ağırlıkla kaynağının Somali olduğu anlaşılmaktadır. Somali'nin, komşusu olan her ülke ile sorun yaşamasına neden olan bir veya birkaç önemli anlaşmazlık konusu bulunduğu görülmektedir.

Afrika Boynuzu bölgesinin iki önemli aktörü olan Etiyopya ve Kenya'nın Somali'yle olan sınır sorunu, mülteci/göçmen sorunu,

\section{7}

Güvenlik Stratejileri

Cilt: 16

Say1: 36 
El Şebab'ın Kenya'da gerçekleştirdiği saldırılar sonrasında Kenya'ya sığınmış Somalililerin yaşadığı kampların kapatılma ihtimali, bölgenin etnik dağılım ve klan/kabile sorunu da kalıcı barış ve güvenliğin önünde bir engel olarak kalmaya devam etmektedir. Etiyopya tarafindan 2006 yılında İslam Mahkemeleri Birliği'ne karşı yapılan harekâtın Somali tarafindan işgal olarak değerlendirilmesi ile iki devlet arasındaki tarihsel düşmanlık ve rekabet sorunların çözülmesini zorlaştırmaktadır. Etiyopya, başkent Addis Ababa'da bulunan AfB ana karargâhına, Kenya'da BM'nin Afrika karargâhına ev sahipliği yapması sebebiyle Afrika diplomasinin en yoğun yaşandığı ülkelerdir. Bu konumları itibariyle Somali'deki iç sorunların çözülmesi yönünde gayret gösterdiklerinde bölge güvenliğine katk1 sağlayabileceklerdir. AFRICOM Afrika Boynuzu Birleşik Müşterek Görev Kuvveti, Fransa, Çin, Japonya, İtalya gibi ülkelerin askerî üslerine ev sahipliği yapan Cibuti; bekasını dışa bağımlı bir politikayla devam ettirme gayretindedir.

Afrika ile ilişkilerde Türkiye dâhil diğer tüm ülke ve uluslararası kuruluşların; kalkınmayla birlikte güvenlik, kalkınmayla birlikte diplomasi, kalkınmayla birlikte demokrasi stratejisine öncelik vermesi gerekmektedir. Afrika için temel gereksinim kalkınma olduğundan her türlü faaliyetin kalkınma ekseninde ele alınması, yapılan faaliyetin kabul edilirliğini de etkinliğini de artıracaktır. Aynı şekilde savunma ile birlikte diplomasinin güçlü girdisi de yapılan faaliyeti daha sağlıklı ve kalıcı kılacaktır. $\mathrm{Bu}$ yaklaşımın Türkiye ve $\mathrm{AB}$ tarafından büyük ölçüde hayata geçirilmekte olduğu görülmektedir.

Afrika Boynuzu bölgesinde onlarca yıldır devam eden ve bölgede kronikleşmiş sorunlara çözüm paydaşlarından biri olmaya istekli olan ve bu yönde iradesini de gösteren Türkiye, bu bölgenin barış ve istikrar içinde geleceğine güvenle bakması için, özellikle Somali'de "elini taşın altına koymuş" ve tarihi bir misyon üstlenmiştir. Somali'de kurduğu askerî eğitim ve öğretim tesisleri, Somali'nin en temel gereksinimi olan "güvenlik" konusunda somut, yararlı ve bekayı artırıcı katkı sağlamıştır. Türkiye'nin güvenlik konusunu kalkınma ile birlikte ele alması, güvenlik ve refah dengesinin koordineli yükseltilmesi çaba ve çalışmaları Somali başta olmak üzere bu bölgede takdirle karşılanmaktadır. 


\section{Summary}

With its young workforce and its rich underground and aboveground national resources, the continent of Africa is a strong candidate to stand out as an actor, which develops, changes and renews itself in the 21st century and to take roles that are more active in the global order. The Horn of Africa, which constitutes the African shores of the Gulf of Aden in the east of this great continent, and the Gulf of Guinea in the west of the continent are geostrategically the keys to the security of the continent. The security problems arising in these two regions have the capacity to affect negatively the security of Africa as a whole and even the security of the global system to a certain extent.

When evaluated within the framework of the Regional Security Complex, the security problems in the Horn of Africa with Somalia as its center have historical, cultural, ethnic, socio-economic, political, and military foundations. Perceptions of amity-enmity fed on these foundations trigger the conflict dynamics instead of cooperation dynamics among the states sharing the same region.

This study defends the argument that the ability to generate regional solutions to the regional problems has a great role in ensuring lasting peace and stability within the framework of Regional Security Complex Theory. Horn of Africa region has been struggling with a maelstrom of civil war, conflict, instability, and poverty especially originating from Somalia since 1992. As it has been conceptualized through the regional security complex theory, Somalia has become a global problem, which has not been yet resolved because of the instability occurring due to the historical enmity and hostilities between the regional states for nearly 30 years.

"New Partnership Agreement" which states the commitments of the international community to Somalia and their expectations from the Somalia administration was signed during a high-level Somalia Conference in London on 11 May 2017. The Security Pact adopted in the conference covers the structures constituting of financial and consultancy support to be provided to the security reforms by the international participants in terms of ensuring national security in Somalia. Receiving the international organizations including the United Nations and 
international community, Somalia has not yet fully established the state institutions and authority, which Weber defined as the monopoly of the

Güvenlik Stratejileri

Cilt: 16

Sayı: 36 legitimate use of violence. State control has not been established in every part of the country, the acts of violence have not been prevented by the legitimate law enforcement actors, and Somalia has continued to rank second after Yemen in the fragile states index.

The subject matters threatening the security of Horn of Africa region cannot be limited to terrorism, clan/tribe, piracy, drought, food, and water. In the region, many subject matters ranging from democracy to human rights, from economy to education continue to exist as the cause of structural violence. The international actors take responsibility to eliminate the structural problems in the Horn of Africa region and to prevent prominent security threats. Within the framework of Regional Security Complex Theory, actors try to prevent regional problems from harming the global system.

In their relations with Africa, all the international organizations and all the countries including Turkey should prioritize the strategy of "security along with development, diplomacy along with development, democracy along with development". Since the basic need of Africa is development, performing all kinds of activities within the axis of development will increase the acceptability of the activity performed. Likewise, the strong input of diplomacy along with defense will also make the activities performed healthier and more permanent.

In the strategies put forth by many states such as the USA and Turkey and by international organizations such as the EU, the development-indexed economic and socio-cultural dimensions are parts of these strategies, as well as the political and security dimensions within a comprehensive approach. One can observe that this approach is implemented in a great deal by Turkey and by the EU. In order to overcome possible future threats and risks, it is considered necessary for the international organizations and states like Turkey, which has started to show a closer interest to the region recently, to correctly identify the security dimension of the region. 
Bölgesel Güvenlik Kompleksi Teorisi Kapsamında

Somali ve Afrika Boynuzu'nun Güvenliği; Aktörler, Tehditler ve Riskler

KAYNAKÇA

Kitaplar

ARMAOĞLU, Fahir, 20. Yüzyıl Siyasi Tarihi, Alkım Yayınevi, İstanbul, 2012.

BUZAN, Barry, People, States and Fear: The National Security Problem in International Relations, Wheatsheaf Books Ltd., Brighton, Sussex, 1983.

BUZAN, Barry and WAEVER, Ole, Regions and Powers: The Structure of International Security, Cambridge University Press, New York, 2003.

CAMPBELL, Kurt M. et al, The Age of Consequences: The Foreign Policy and National Security Implications of Global Climate Change, Center for Strategic and International Studies (CSIS), ABD, November 2007, https://www.researchgate.net/publication/ 235149499_The_Age_of_Consequences_The_Foreign_Policy_and_National_Security_ Implications_of_Global_Climate_Change (Erişim Tarihi: 21.11.2020).

CHRISTENSEN $\bar{N}$, Jens Hesselbjerg et al, Regional climate projections, Climate change 2007: The physical science basis, Contribution of Working Group I to the Fourth Assessment Report of the Intergovernmental Panel on Climate Change, 847-940, https://www.researchgate.net/publication/284652431_Regional_climate_projections_Clima te change 2007_The_physical_science_basis (Erişim Tarihi: 21.11.2020).

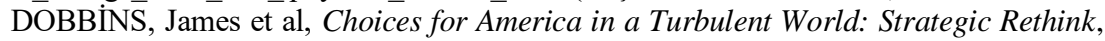
RAND Corporation, Santa Monica, 2015, https://www.rand.org/pubs/research_reports /RR1114.html (Erişim Tarihi: 21.11.2020).

HANSEN, Stig Jarle, Al-Shabaab in Somalia: The History and Ideology of a Militant Islamist Group, Oxford University Press, 1st Edition, 15 Ocak 2013.

ÖKTEM, Akif Emre ve KURTDARCAN, Bleda R. Deniz Haydutluğu ve Korsanlik: Tarihi ve Hukuki Boyutlarlyla, Denizler Kitabevi, Birinci Baskı, İstanbul, 2011.

PARKER, Geoffrey, Cambridge Savaş Tarihi, Türkiye İş Bankası Kültür Yayınları, 2'nci Basim, İstanbul.

ŞAHIN, Güngör (Ed.), Somali Barış, İstikrar ve Kurumsallaşma, Milli Savunma Üniversitesi Yayınları, İstanbul, 2019.

WOLFERS, Arnold, Discord and Collaboration: Essays on International Politics, The John Hopkins Press, Baltimore, 1962.

\section{Makaleler}

Arslan, İbrahim, "21. Yüzyılda Afrika-Avrupa Birliği İlişkileri: İki Birlik, Tek Vizyon”, Marmara Avrupa Araştırmaları Dergisi, 2015, Sayı 1, 109-135.

BAHAR, Michael, "Attaining Optimal Deterrence at Sea: A Legal and Strategic Theory for Naval Anti-Piracy Operations", Vanderbilt Journal of Transnational Law, Volume 40, Number 1, 2007, https://papers.ssrn.com/sol3/papers.cfm?abstract_id=982679 (Erişim Tarihi: 21.11.2020).

BAYSAL, Başar, "20 Years of Securitization: Strengths, Limitations and A New Dual Framework", Uluslararası Ilişskiler, 2020, No 67, 3-20.

BİNGÖL, Oktay, “ABD Ulusal Güvenlik Stratejisinin Küresel Uygulayıcıları: Coğrafi Muharip Komutanlıklar”, Güvenlik Stratejileri Dergisi, 2014, Sayı 19, 133-166.

BİNGÖL, Oktay, "Somali'de Barış ve Kalkınma Sürecinde Türkiye'nin Rolü”, Gazi Akademik Bakış, Cilt 7, Sayı 13, Kış 2013, 81-106. 
KAPUR, Saloni and MABON, Simon, "The Copenhagen School Goes Global: Securitization in the Non-West", Global Discourse, 2019, No 1, 1-4.

KARAGUL, Soner, ve ARSLAN, İbrahim, "Afrika'da Barış ve Güvenliğin İnşasında Kıtasal Yaklaşım: Afrika Barış ve Güvenlik Mimarisi”, Güvenlik Stratejileri Dergisi, 2014, sayı:19, 57-98.

Say1: 36

STARR, Joyce R., "Water Wars", Foreign Policy, No. 82 (Spring, 1991), 17-36 82, https://www.jstor.org/stable/1148639?seq=1\#metadata_info_tab_contents (Erişim Tarihi: 21.11.2020).

WILLIAMS, Paul D. "After Westgate: Opportunities and Challenges in the War Against Al-Shabaab", International Affairs, The Royal Institute of International Affairs, 2014,. https://ciaotest.cc.columbia.edu/journals/riia/v90i4/f_0032208_26204.pdf (Erişim Tarihi: 21.11.2020).

\section{İnternet Kaynakları}

African Union Website, "Constitutive Act of the African Union", https://au.int/sites/ default/files/pages/34873-file-constitutiveact_en.pdf(Erişim Tarihi: 07.06.2020).

AMISOM Website, "Al Shabaab Using Child Soldiers in Desperate Effort to Control Somalia", http://amisom-au.org/2016/03/al-shabaab-using-child-soldiers-in-desperateeffort-to-control-somalia/ (Erişim Tarihi: 07.06.2020).

AMISOM Website, "BBC's Tomi Oladipo Interviews SRCC Madeira", http://amisomau.org/2016/03/8157, (Erişim Tarihi: 07.06.2020).

AYBAR, SEDAT, “Afrika Boynuzu'nun Kapasite İnșasında Türkiye'nin Rolü”, TASAM, https://tasam.org/tr-TR/Icerik/39026/afrika_boynuzunun_kapasite_insasinda_ turkiyenin rolu (Erişim Tarihi: 07.06.2020)

Council of the European Union, The Africa-EU Strategic Partnership-A Joint AfricaEU Strategy, Lisbon, 9 December 2007, https://www.consilium.europa.eu/uedocs/ cms_data/docs/pressdata/en/er/97496.pdf (Erişim Tarihi: 08.06.2020).

Critical Threats Sitesi, "Al Shabaab Leadership Profiles", http://www.criticalthreats.org/ somalia/al-shabaab-leadership (Erişim Tarihi: 07.06.2020).

Encyclopedia Britannica, "Horn of Africa", http://global.britannica.com/place/Hornof-Africa (Erişim Tarihi: 07.06.2020).

Fund for Peace, "Fragile States Index 2020", https://fragilestatesindex.org/ (Erişim Tarihi: 06.06.2020).

EU Naval Force-Somalia Operation ATALANTA Website, "Mission", https://eunavfor.eu/mission/ (Erişim Tarihi: 09.06.2020).

EU Naval Force-Somalia Operation ATALANTA Website, "MSCHOA", https://eunavfor.eu/mschoa/ (Erişim Tarihi: 06.06.2020).

EUCAP Somalia Website, "Mission Background", https://www.eucap-som.eu/aboutus/ Erişim Tarihi: 18 Aralık 2015.

European Commission, African Peace Facility Annual Report 2014, 2015, https://africa-eu-partnership.org/sites/default/files/documents/african_peace_facility_ annual_report_2014_en.pdf (Erişim Tarihi: 08.06.2020).

European Council and Council of the European Union Website, "EU-Africa Relations", http://www.consilium.europa.eu/en/policies/eu-africa (Erişim Tarihi: 08.06.2020). 
Bölgesel Güvenlik Kompleksi Teorisi Kapsamında

Somali ve Afrika Boynuzu'nun Güvenliği; Aktörler, Tehditler ve Riskler

European Council and Council of the European Union Website, "Somalia: EU Extends Training Mission", https://www.consilium.europa.eu/en/press/press-releases/2015/ 03/16/eutm-somalia-training-mission/ (Erişim Tarihi: 09.06.2020).

European External Action Service Website (EEAS), "Common Security And Defence Policy European Union Training Mission - Somalia", http://www.eeas.europa.eu/archives/ docs/csdp/missions-and-operations/eutm-somalia/docs/factsheet_eutm_somalia_en.pdf (Erişim Tarihi: 08.06.2020).

European External Action Service Website (EEAS), "HQ Organisation Chart", 1 October 2020, https://eeas.europa.eu/sites/eeas/files/2020-01-10-eeas_2.0_orgchart.pdf (Erişim Tarihi: 23.11.2020).

European Union European External Action Service Website (EEAS), "Military and Civilian Missions and Operations", https://eeas.europa.eu/headquarters/headquartershomepage/area/geo_en (Erişim Tarihi: 08.06.2020).

European External Action Service Website (EEAS), "The Common Security and Defence Policy (CSDP)", https://eeas.europa.eu/topics/common-security-and-defencepolicy-csdp_en (Erişim Tarihi: 08.06.2020).

Website, "About the European External Action Service (EEAS)", https://eeas.europa.eu/headquarters/headquarters-homepage/82/about-european-

external-action-service-eeas_en (Erişim Tarihi: 09.06.2020).

Hiiraan Online, "Drought-hit Somalia at 'Tipping Point': UN", 31 March 2016, http://www.hiiraan.com/news4/2016/Mar/104812/drought_hit_somalia_at_tipping_poi nt_un.aspx (Erişim Tarihi: 07.06.2020).

Home Office, "Country Policy and Information Note Somalia: Al Shabaab", Version 3.0, November 2020, https://assets.publishing.service.gov.uk/government/uploads/ system/uploads/attachment_data/file/933800/Somalia-_Al_Shabaab_-_CPIN_-

_V3.0e.pdf (Erişim Tarihi: 06.06.2020).

JENKINS, Orville Boyd, "Race and Ethnicity in the Horn of Africa", 25 January 2006, http://strategyleader.org/peopledefinitions/raceandethnicity.html (Erişim Tarihi: 07.06.2020 Marine Insight, "18 Anti-Piracy Weapons for Ships to Fight Pirates”, 25 October 2019, https://www..com/marine-piracy-marine/18-anti-piracy-weapons-for-ships-to-fight-pirates/ (Erişim Tarihi: 07.06.2020).

New World Encyclopedia, "Horn of Africa", http://newworld encyclopedia.org/entry/Horn_of_Africa (Erişim Tarihi: 06.06.2020).

North Atlantic Treaty Organization Website, "Cooperation with the African Union", 16 November 2020, https://www.nato.int/cps/en/natohq/topics_8191.htm (Erişim Tarihi: 22.11.2020).

North Atlantic Treaty Organization Website, "NATO and the Republic of Djibouti consolidate their cooperation", www.nato.int/cps/en/natohq/news_118880.htm (Erişim Tarihi: 07.06.2020).

OCHA, "Somalia: Floods force thousands from their homes", 23 October 2019, https://www.unocha.org/story/somalia-floods-force-thousands-their-homes (Erişim Tarihi: 07.06.2020). 
Güngör ŞAHIN

914

Güvenlik

Stratejileri

Cilt: 16

Say1: 36

Perry-Castañeda Library Map Collection, "Clan Distribution", University of Texas Libraries, https://legacy.lib.utexas.edu/maps/africa/txu-pclmaps-oclc-795784383somalia_2012.jpg (Erişim Tarihi: 07.06.2020).

Saylor Academy, "Ethnic Groups in Africa", 2011, http://www.saylor.org/site/wpcontent/uploads/2011/04/ Ethnic-groups-in-Africa.pdf (Erişim Tarihi: 07.06.2020).

The African Union Mission in Somalia (AMISOM) Website, "AMISOM Background", https://amisom-au.org/amisom-background/ (Erişim Tarihi: 08.06.2020). The African Union Mission in Somalia (AMISOM) Website, "AMISOM Mandate", https://amisom-au.org/amisom-mandate/ (Erişim Tarihi: 07.06.2020).

TSK Gnkur.Bşk.lığı Resmî Sitesi, “Türkiye'nin Barışı Destekleme Harekâtına Katkıları”, https://www.tsk.tr/Sayfalar?viewName=BarisiDestekleme (Erişim Tarihi: 08.06.2020).

Türkiye Cumhuriyeti Dışişleri Bakanlığı, "2015 Y1lına Girerken Dış Politikamız", s. 107, http://www.mfa.gov.tr/site_media/html/2015-yilina-girerken-dis-politikamiz.pdf (Erişim Tarihi: 07.06.2020).

United Nations, The United Nations and Somalia (1992-1996), The United Nations Blue Books Series, Volume VIII, Department of Public Information, New York, 1996, p. 3-4, https://digitallibrary.un.org/record/205118 (Erişim Tarihi: 06.06.2020).

UN High Commissioner for Refugees, "Somalia March 2016: Total Internally Displaced Persons", 12 March 2016, http://reliefweb.int/map/somalia/somalia-march2016-total-internally-displaced-persons (Erişim Tarihi: 07.06.2020).

United Nations Peacekeeping, "Where We Operate", https://peacekeeping.un.org/ en/where-we-operate (Erişim Tarihi: 07.06.2020).

UNOSOM I (United Nations Operation in Somalia I), April 1992-March 1993, https://peacekeeping.un.org/sites/default/files/past/unosomi.htm (Erişim Tarihi: 06.06.2020).

UNOSOM II (United Nations Operation in Somalia II), Mart 1993-Mart 1995, https://peacekeeping.un.org/sites/default/files/past/unosom2.htm (Erişim Tarihi: 06.06.2020).

Wikipedia, "Camp Lemonnier", https://en.wikipedia.org/wiki/Camp_Lemonnier (Erişim Tarihi: 20.11.2020).

YAN, Holly, "What is Al-Shabaab, and What does It Want?", CNN, 22 February 2015, http://edition.cnn.com/2014/12/02/world/africa/al-shabaab-explainer/ (Erişim Tarihi: 07.06.2020). 